\title{
Os significados da democracia segundo os brasileiros
}

\author{
José Álvaro Moisés \\ Departamento de Ciência Política \\ Núcleo de Pesquisa de Políticas Públicas \\ Universidade de São Paulo
}

\begin{abstract}
Resumo: 20 anos depois de reinstalada a democracia no Brasil, a maioria dos brasileiros apóia o regime, mas desconfia das instituições democráticas. 0 artigo examina os significados atribuídos à democracia por pessoas comuns com base na análise das respostas à pergunta aberta "O que é democracia". O estudo se baseia em análises bivariadas e multivariadas de dados de pesquisas coordenadas pelo autor em 1989, 1990, 1993 e 2006. Os testes tiveram por objetivo verificar os significados mais importantes do conceito, assim como os seus determinantes, de modo a permitir um conhecimento mais aprofundado sobre a crescente adesão normativa dos brasileiros à democracia. Os resultados mostram que os brasileiros definem a democracia em termos tanto de liberdades como de procedimentos institucionais; surpreendentemente, o conteúdo relativo à dimensão social da democracia tem pouco impacto nos resultados. Ao longo de quase 20 anos, os brasileiros confirmam a sua crescente adesão à democracia, e combinam sobre o conceito uma ideia normativa com outra de natureza pragmática, mas que se refere à função das instituições. Isoladas, essas dimensões dizem pouco, mas, juntas, definem a natureza singular do processo democrático e têm relação com a sua qualidade.
\end{abstract}

Palavras-chave: democracia; apoio político; instituições representativas; cultura política

Abstract: 20 years after democracy was reestablished in Brazil, Brazilians give support to the democratic regime but distrust public institutions. The paper exams the meanings of democracy according to common people's answers to an open-end question: "What is democracy?", included in surveys undertaken by the author in 1989, 1990, 1993 and 2006. Bivariate and multivariate statistical analyses were undertaken in order to advance the knowledge about the meanings of democracy, its determinants and the nature of the growing normative adherence to the democratic regime in the country. Data has shown that Brazilians define democracy in terms of liberties, freedom and institutional procedures; surprisingly the dimension relative to social benefits has no important impact on the results. Both definitions, related to a normative and a pragmatic perspectives, are relevant for democratic consolidation and the quality of democracy, and are integral components of the democratic process.

Keywords: democracy; political support; representative institutions; political culture 


\section{Introdução ${ }^{1}$}

Perto de completar um quarto de século depois de ter sido restabelecida no Brasil, a democracia é o regime político preferido por mais de $2 / 3$ dos cidadãos brasileiros $^{2}$. O significado desse fato para a história política contemporânea do país não pode, no entanto, ser bem compreendido se não se levar em conta que, em mais de um século de regime republicano, os brasileiros experimentaram as virtudes do regime democrático em apenas dois períodos de duas décadas cada, ou seja, entre 1946 e 1964 e, mais recentemente, entre 1988 até o presente. Fora desses curtos períodos de tempo, predominaram no país, durante a maior parte do século XX, sistemas políticos oligárquicos, autoritários ou semi-liberais que, por definição, não asseguravam as liberdades fundamentais, a competição política, a participação popular ou os direitos de cidadania. Em uma perspectiva temporal longa, portanto, a democracia é um fenômeno político relativamente novo no Brasil e, ao mesmo tempo, frágil e descontínuo na experiência política dos brasileiros. Por si só, esta é uma razão importante para se tentar avançar o conhecimento sobre o que os brasileiros pensam a respeito do regime democrático.

No presente, diferente de outros períodos de sua história, a atitude positiva a respeito da democracia é majoritária no país e, mais importante que isso, a adesão dos cidadãos ao regime democrático é validada pela rejeição de mais de 2/3 do público a alternativas antidemocráticas, como a volta dos militares ao poder ou o estabelecimento de um sistema de partido único (Gráfico 1). A relevância do apoio estável dos cidadãos ao regime democrático foi enfatizada por diversos autores da literatura comparada sobre democratização. Nesse sentido, Shin (2005) e Linz e Stepan (1996), ao discutirem os diferentes aspectos dos processos de consolidação democrática, consideraram que a dimensão atitudinal é uma das mais importantes, uma vez que

\footnotetext{
${ }^{1}$ Versão revista do texto apresentado à mesa redonda "Os significados da democracia na América Latina e suas medidas", IV Congresso da Associação Latino-americana de Ciência Política - ALACIP, 5-7/8/08, Costa Rica e ao / Seminário Internacional de Estudos sobre o Legislativo - 20 anos da Constituição, 9.11/9/08, Departamento de Sociologia da Universidade de Brasília.

2 Segundo o World Values Survey, da Universidade de Michigan - que cobre atualmente mais de $80 \%$ da população mundial - a democracia é hoje o regime político preferido pela maioria dos consultados (INGLEHART, 2003). O Latinobarometro, por sua vez, confirma os resultados para a América Latina: em que pesem casos específicos de alguns países, a preferência pela democracia supera a marca dos $50 \%$ no continente ao longo de mais de dez anos (Informe Latinobarometro 2007, $<$ www.latinobarometro.org $>$ ).
} 
“um regime democrático só está consolidado quando uma forte maioria da opinião pública acredita que os procedimentos e as instituições democráticas constituem o modo mais apropriado de governar a vida coletiva numa sociedade como a deles, e quando o apoio a alternativas anti-sistêmicas é pequeno ou isolado da atitude predominante entre as forças pró-democráticas" (LINZ e STEPAN, 1996, p. 6).

Essa observação reatualiza a perspectiva predominante em parte da literatura que tratou do tema e que, de modo geral, se apoiou nas conhecidas formulações de Max Weber (1974), segundo as quais, a legitimidade atribuída às instituições pelos cidadãos é um aspecto central do funcionamento da vida política de qualquer regime e, no caso da democracia, é particularmente mais relevante porque a aquiescência dos cidadãos às decisões que afetam a sua vida - a exemplo das políticas públicas - não depende da coerção política, mas é voluntária.

A despeito disso, pesquisas recentes sobre o tema demonstraram que o crescimento da adesão normativa do público de massas à democracia convive com um paradoxo caracterizado por proporções muito altas de desconfiança das instituições democráticas (MOISÉS, 1995; 2008a; 2008b), inclusive na maior parte dos países latino-americanos. É como se as pessoas comuns ouvidas pelas pesquisas de opinião estivessem dizendo, por uma parte, que amam a democracia, mas, de outra que, se não odeiam, têm sentimentos contraditórios ou ambíguos a respeito de normas, procedimentos e regras que caracterizam as instituições democráticas, cuja função é assegurar a sua participação na competição pelo poder e nos mecanismos pelos quais as decisões públicas são tomadas. Com efeito, sem que os membros da comunidade política sejam motivados a recorrer às instituições e referenciar a sua ação por elas, as principais promessas da democracia - como a liberdade política, a igualdade dos cidadãos perante a lei, os seus direitos individuais e coletivos, e a obrigação dos governos de prestarem contas à sociedade de suas ações - ficam limitadas às formalidades da ordem constitucional. Criadas para assegurar a distribuição do poder na sociedade e também a possibilidade de os cidadãos, em sua condição de eleitores, avaliarem e julgarem o desempenho dos que governam em seu nome, o descrédito ou a desvalorização pública das instituições podem provocar o seu esvaziamento e a perda do seu significado (MOISÉS, 2007).

Os dados da Tabela 1 demonstram, com efeito, que, a despeito de a adesão normativa à democracia ser majoritária no Brasil, os brasileiros desconfiam das instituições democráticas em geral e, em particular, dos partidos políticos, do Congresso Nacional e do sistema judiciário. Os índices mais altos de confiança se referem a poucas instituições públicas e privadas que são baseadas em estruturas 
hierárquicas, como a igreja e as forças armadas; além disso, os brasileiros também se caracterizam por sua escassa confiança nas pessoas - em especial, as que estão longe de sua intimidade ou da convivência caracterizada por laços de sangue -, como colegas de trabalho e estranhos em geral. Os baixos índices de confiança interpessoal entre os brasileiros oferecem, assim, uma alternativa para se entender os também baixos níveis de participação política no país. Testes de associação realizados pelo autor (mas não apresentadas aqui) tendem a confirmar essa hipótese, ou seja, que depositando pouca confiança uns nos outros, os brasileiros padecem de um estímulo importante para vencer os obstáculos que dificultam a decisão de enfrentar os dilemas da ação coletiva.

Tabela 1

Confiança em pessoas e em instituições - Brasil, junho, 2006

\begin{tabular}{|l|l|l|l|l|l|}
\hline Confiança interpessoal & Nenhuma & Pouca & Alguma & Muita & Média \\
\hline Família & 1,5 & 9,9 & 16,0 & 72,5 & 2,59 \\
\hline Pessoas que frequentam mesma igreja & 11,3 & 32,6 & 37,7 & $18,4 q$ & 1,63 \\
\hline Amigos & 12,3 & 39,1 & 34,6 & 14,0 & 1,5 \\
\hline Vizinhos & 21,3 & 42,1 & 29,3 & 7,2 & 1,22 \\
\hline Colegas de trabalho & 22,3 & 42,3 & 27,8 & 7,5 & 1,21 \\
\hline Maioria das pessoas & 22,3 & 54,5 & 21,2 & 2,1 & 1,03 \\
\hline Confiança nas instituições & Nenhuma & Pouca & Alguma & Muita & Média \\
\hline Bombeiros & 2,8 & 11,1 & 32,4 & 53,7 & 2,37 \\
\hline Igreja & 6,0 & 18,7 & 34,3 & 40,9 & 2,10 \\
\hline Forças Armadas & 9,8 & 28,9 & 40,1 & 21,3 & 1,73 \\
\hline Televisão & 8,0 & 34,1 & 46,0 & 11,9 & 1,62 \\
\hline Poder Judiciário & 13,7 & 42,0 & 33,4 & 11,0 & 1,42 \\
\hline Presidente & 23,0 & 33,8 & 31,2 & 12,0 & 1,32 \\
\hline Polícia & 18,8 & 43,2 & 29,4 & 8,7 & 1,28 \\
\hline Leis do País & 20,8 & 41,3 & 30,6 & 7,3 & 1,24 \\
\hline Sindicatos & 19,4 & 44,3 & 30,6 & 5,7 & 1,23 \\
\hline Governo & 24,9 & 40,8 & 28,5 & 5,9 & 1,15 \\
\hline Congresso Nacional & 26,7 & 45,9 & 22,6 & 4,7 & 1,05 \\
\hline Empresários & 26,9 & 44,3 & 25,7 & 3,0 & 1,05 \\
\hline Partidos Políticos & 36,8 & 44,2 & 16,9 & 2,1 & 0,84 \\
\hline
\end{tabular}

Nota: A tabela apresenta frequências simples e a confiança varia de 0 a 3; as médias foram calculadas com base neste intervalo. As médias mais altas são para a confiança na família, nos bombeiros e na igreja, e as mais baixas para os partidos, a maioria das pessoas, os empresários e o Congresso Nacional. 
Uma vez que as atitudes contraditórias de adesão à democracia e de desconfiança das instituições são vistas por parte da literatura como referentes a uma única e mesma dimensão do fenômeno de apoio político, analistas céticos têm sido levados a questionar se as expressões de apoio popular a muitas das novas democracias não são desprovidas de sentido. Com efeito, esses céticos argumentam, em primeiro lugar, que a despeito de convalidarem o estabelecimento dos novos regimes democráticos através da sua participação em eleições para formar governos, as populações dos países pobres ou em desenvolvimento estão mais preocupadas com as suas necessidades econômicas e sociais do que com as virtudes ou os valores da democracia. Além disso, os que sustentam essas posições também consideram que os cidadãos desses países - em muitos casos caracterizados por baixos níveis de escolaridade e de renda e, portanto, em tese, detentores de cognição política insuficiente para compreender a complexidade do sistema democrático -, ao expressarem apoio à democracia podem estar simplesmente manifestando a sua simpatia a uma noção cercada de conotação positiva - particularmente após o fracasso de suas alternativas em escala mundial que, ademais, teria apenas um sentido vago para eles. Os céticos sugerem também que, devido à difusão internacional das imagens positivas do regime democrático após os acontecimentos que culminaram com a queda do Muro de Berlim, no final dos anos 80, a atual adesão do público de massas à democracia representativa, sob crescente influência dos meios massivos de comunicação, pode estar traduzindo, mais do que a aceitação de valores políticos, o desejo das pessoas comuns de conquistarem os níveis de renda e de consumo usualmente associados com a realidade das democracias ocidentais. Por outras palavras, mais do que expressar a escolha pelos princípios de um regime político específico, a preferência majoritária pela democracia seria, de fato, uma função de escolhas de outra natureza (SCHAFFER, 1998; BAVISKAR e MALONE, 2004; SCHEDLER e SARSFIELD, 2004; DALTON, SHIN e JOU, 2007).

As implicações deste cenário, caso a realidade empírica viesse a confirmar essas previsões, são bem conhecidas: elas apontariam para a possibilidade de formação de uma democracia sem democratas que, a exemplo da República de Weimar, entre 1919 e 1933 (GAY, 1978), poderia colocar em risco os novos regimes, na eventualidade de enfrentarem crises econômicas e sociais (déficits fiscais, quedas de investimento, inflação, desemprego, migrações em massa, etc.), às quais os governos e as lideranças políticas do dia não fossem capazes de responder com a eficiência e a agilidade necessárias. Assim, mesmo tendo em conta que os últimos trinta anos de mudanças de regime político mostraram alguns países avançando o processo de sua democratização a despeito das crises econômicas e sociais enfrentadas na fase final da transição, como Argentina, Brasil e Espanha, a hipótese anterior envolve um dilema político e uma exigência de 
conhecimento: sem menosprezar o que já sabemos a respeito, é preciso avançar mais na análise dos conteúdos atribuídos pelos cidadãos comuns ao conceito de democracia nos novos sistemas políticos surgidos da terceira onda de democratização mundial. Assim, como os entrevistados de pesquisas de opinião definem o conceito de democracia? Essa definição permite distinguir a democracia de outros regimes políticos? E no caso de países como o Brasil, cujas estruturas econômicas e sociais são caracterizadas por profundas desigualdades, os indivíduos consultados pelas pesquisas expressam preferência por conteúdos relacionados com suas carências materiais, em detrimento de definições relativas aos valores e aos procedimentos típicos da democracia?

Este artigo procura responder a algumas dessas indagações com base na análise de dados de quatro pesquisas nacionais de opinião e atitudes dirigidas pelo autor entre 1989 e $2006^{3}$. A análise é exploratória e o estudo examina o significado do conceito de democracia para as pessoas comuns a partir da pergunta aberta "Para você, o que é democracia?", incluída em quatro surveys realizados em um espaço de 17 anos. A codificação das respostas foi feita com o objetivo de elucidar os significados mais importantes do conceito, ou seja, se eles são relativos à dimensão de procedimentos, de princípios e liberdades ou de conteúdos substantivos, de modo a permitir avançar o nosso conhecimento sobre a crescente adesão dos brasileiros ao regime democrático. A análise empírica mais extensa utilizou os dados do survey de 2006, começando pela descrição de frequências e, em seguida, pela análise fatorial de variáveis que, em tese, poderiam estar associadas com a respostas à pergunta aberta mencionada. Por último são apresentados os resultados de uma análise de regressão logística com a variável construída com base nas respostas dos entrevistados que souberam definir o que é a democracia. O objetivo, neste caso, era entender os determinantes das respostas.

Os resultados mostram que os brasileiros associam a democracia majoritariamente a uma noção normativa fundamental, relativa às liberdades, mas, também, com os procedimentos desse regime. Embora também citado nas entrevistas, o conteúdo relativo à dimensão social ou à substantivação da democracia tem surpreendentemente pouco peso no conjunto das amostras. Ou

\footnotetext{
3 As pesquisas "Democratização e Cultura Política”, realizadas em 1989 (setembro e dezembro), 1990 (março) e 1993 (março), foram elaboradas e dirigidas por José Álvaro Moisés, e realizadas com apoio da Fundação de Amparo à Pesquisa do Estado de São Paulo - FAPESP, Conselho Nacional de Pesquisa e Desenvolvimento Tecnológico - CNPq e Fundação Ford, tendo contado, em alguns casos, com a parceria do Datafolha. Os bancos de dados correspondentes podem ser obtidos por solicitação ao autor ou ao Centro de Estudos de Opinião Pública - CESOP, onde estão depositados para uso público. A pesquisa "A Desconfiança dos Cidadãos das Instituições Democráticas", realizada em 2006 (junho), foi dirigida por José Álvaro Moisés e Rachel Meneguello (UNICAMP), com apoio da FAPESP e do CNPq. Dados da pesquisa "Cultura Política e Cidadania", da Fundação Perseu Abramo, realizada em 1997, também são utilizados neste estudo, assim como dos surveys ESEB, de 2002 e 2006, coordenados por Rachel Meneguello, do CESOP/Unicamp.
} 
seja, desde que a democracia está vigente no país, a partir de 1988, os brasileiros confirmaram a sua adesão ao regime em termos que se referem, ao mesmo tempo, às liberdades fundamentais e aos procedimentos institucionais, combinando, portanto, uma ideia normativa ligada aos princípios democráticos com outra de natureza prática, relativa ao desempenho das instituições. As duas dimensões são importantes e estão relacionadas com a qualidade da democracia que, precisamente, supõe a integração desses fatores (DIAMOND e MORLINO, 2005).

\section{Sobre as definições de democracia}

A experiência de pesquisas de opinião e de atitudes políticas mostra que, ao serem interrogadas sobre o que pensam do conceito de democracia, as pessoas comuns podem mostrar-se com frequência hesitantes ou mesmo perplexas diante de um estimulo que não é usual em sua vida cotidiana. Em tal situação, não é incomum os entrevistadores obterem como primeira reação afirmações como "Eu não sei bem, preciso pensar mais...", para depois ouvirem um comentário complementar como "Eu acho que é uma coisa importante..." ou "Acho que precisamos dela...", recebendo respostas tópicas ou incompletas. Em sentido semelhante, Dalton, Shin e Jou (2007) lembraram, recentemente, em um texto dedicado ao exame do "entendimento da democracia em lugares improváveis", que em 1989 um estudante chinês que participava das famosas manifestações anti-autoritárias na praça de Tiananmen portava um cartaz com a mensagem: "Eu não sei o que significa democracia, mas sei que precisamos dela".

Que implicações têm essas observações? Ambas apontam para duas questões importantes para a pesquisa do tema. Em primeiro lugar, mostram as dificuldades que uma parte das pessoas comuns enfrenta ao serem colocadas diante da solicitação de definir um conceito complexo como o de democracia: afora as que se sentem à vontade para responder por conta de sua formação educacional ou de sua experiência, muitas hesitam, mencionam aspectos parciais, respondem equivocadamente ou simplesmente não sabem responder. O problema não diz respeito apenas aos cidadãos de nações pobres ou em desenvolvimento, que estabeleceram o regime democrático nas últimas décadas, mas também aos habitantes de nações ricas ou mais desenvolvidas, onde a experiência democrática é longeva e está consolidada há décadas ou séculos. A literatura sobre a sofisticação e o conhecimento político dos públicos de massa mostrou, já há algum tempo, que as pessoas comuns podem ter limites na sua compreensão do mundo da política por fatores como o seu insuficiente interesse por ela, a pouca centralidade atribuída às diferentes dimensões do sistema político e, principalmente, os seus níveis insuficientes de escolarização ou de educação formal (NEUMAN, 1986). Mesmo em países como os Estados Unidos, Inglaterra ou 
Alemanha verificou-se a existência de porções importantes do público que, não obstante serem favoráveis ao regime democrático e terem ideias sobre ele, têm dificuldades para defini-lo em termos precisos. Nada disso desqualifica as convicções e percepções dos entrevistados, quaisquer que sejam elas, mas sugere que talvez não seja o caso de esperar, por exemplo, que nos países latinoamericanos, da mesma forma que na Rússia, na Ucrânia, no Afeganistão ou na África do Sul, onde os níveis de desigualdades econômicas e sociais afetam a escolarização de importantes contingentes de suas populações e, em consequência, também a sua cognição política, sejam encontradas uma maioria de respostas com graus elevados de elaboração ou de complexidade para a indagação "O que é democracia?". Uma hipótese aparentemente mais realista, neste caso, recomendaria esperar que contingentes minoritários dotados de níveis mais altos de escolarização sejam capazes de responder à pergunta, mas não necessariamente a maioria dos entrevistados; mas essa alternativa desconsidera tanto os efeitos negativos da experiência autoritária para mudar as convicções das pessoas, como a influência de mudanças culturais provocadas por processos de modernização econômica e social (SOARES, 1973; MOISÉS, 1995; INGLEHART e WELZEL, 2005). Em consequência, uma das questões relevantes de pesquisa consiste em saber como respondem os diferentes segmentos do público que passaram por essas experiências, qual a variância das respostas e qual a relação delas com o funcionamento do regime. Ou seja, além de fatores contingenciais - como a difusão internacional da democracia ou sua associação com o êxito econômico de governos do dia -, outras variáveis de efeito mais duradouro também precisar ser levadas em conta na análise do tema. Seu exame precisa levar em conta a sua multidimensionalidade.

Outra questão importante refere-se ao fato de a democracia ter diferentes significados que podem ser expressos diferentemente pelos diferentes segmentos dos públicos de massa. Em si mesmo, o conceito de democracia envolve diferentes conteúdos, formulados e articulados no longo processo histórico de sua formação, os quais resultaram na variedade de significações que ele tem hoje, mas, como é evidente, eles não se opõem ou se anulam. Não é tão simples, então, mesmo para os segmentos mais escolarizados, oferecer de pronto uma definição capaz de sintetizar as diversas significações que o conceito adquiriu ao longo de séculos de desenvolvimento da tradição democrática. Embora pesquisas anteriores tenham, às vezes, sugerido que existe um sentido comum na compreensão geral do termo pelo público, estudos recentes envolvendo países que se democratizaram nas últimas décadas mostraram que as compreensões do conceito de democracia variam bastante entre as nações e entre os seus públicos, sem envolver um padrão único ou completamente definido (BRATTON, MATTES e GYIMAH-BOADI, 2004; CAMP, 2001). Isso também não desqualifica as respostas, mas significa que uma hipótese 
realista levaria a esperar uma resposta capaz de integrar as diferentes dimensões do conceito, menções desagregadas com diferentes significações, traduzindo visões distintas do público a respeito do regime democrático. Além disso, qualquer que seja o percentual de entrevistados capazes de oferecer essas visões, a segunda questão relevante do estudo consiste em saber que fatores estão associados às suas respostas, e quais aspectos do desempenho do regime eles reforçam ou fragilizam.

Na literatura acadêmica, o significado mais usual da democracia se refere aos procedimentos e aos mecanismos competitivos de escolha de governos através de eleições, mas existem outras perspectivas que ampliam a compreensão do conceito, incluindo tanto as dimensões que se referem aos conteúdos da democracia, como também os seus resultados práticos esperados no terreno da economia e da sociedade. Por uma parte, acompanhando a abordagem minimalista de Schumpeter (1950) e a procedimentalista de Dahl (1971), vários autores definiram a democracia em termos de competição, participação e contestação pacífica do poder. Assim, o estabelecimento de um regime democrático implicaria basicamente em condições mínimas como: 1) direito dos cidadãos escolherem governos por meio de eleições com a participação de todos os membros adultos da comunidade política; 2) eleições regulares, livres, competitivas, abertas e significativas; 3) garantia de direitos de expressão, reunião e organização, em especial, de partidos políticos para competir pelo poder; e 4) acesso a fontes alternativas de informação sobre a ação de governos e a política em geral. Essa definição deixa claro que qualquer sistema político que não se baseie em processos competitivos de escolha de autoridades públicas, capazes de torná-las dependentes do voto da massa de cidadãos, isto é, do mecanismo por excelência de accountability vertical, não pode ser definido como uma democracia.

Mas a ênfase minimalista de Schumpeter e de seus seguidores é vulnerável ao que outros autores classificaram como uma "falácia eleitoralista", isto é, a tendência de privilegiar as eleições sobre outras dimensões da democracia (KARL, 2000). De fato, ao definir a democracia essencialmente como um método de escolha de governos dentre as elites que competem pela posição, essa perspectiva desconsidera o fato de que mesmo nações que adotam o mecanismo eleitoral podem conviver com eleições não inteiramente livres, tornando discutíveis os seus resultados. Além disso, a vertente minimalista dá pouca importância ao que acontece com as demais instituições durante a democratização. Instituições como o parlamento, os partidos, o judiciário ou a polícia podem funcionar de forma deficitária ou incompatível com a doutrina da separação de poderes, mesmo convivendo com um regime de regras eleitorais. Exemplos recentes são os casos da Rússia, do Paquistão e, no contexto latino-americano, do Peru sob Fujimori, da 
Bolívia e do Equador na fase de decisão sobre as suas novas constituições, e da Venezuela sob os governos de Chávez.

Em vista de limitações desse tipo, Dahl (1971) ampliou e completou a definição da democracia com sua abordagem das poliarquias, mostrando que para que o princípio de contestação do poder esteja assegurado é também indispensável que condições específicas assegurem a participação dos cidadãos na escolha de governos e, inclusive, a possibilidade de eles próprios serem escolhidos para formáIos; outra característica central da democracia, segundo o autor, é a exigência de responsabilização de governos e lideranças políticas diante dos cidadãos. Essas condições implicam em garantias relativas ao direito de organização e representação da sociedade civil, em especial, em partidos políticos, por intermédio do que a pluralidade de concepções e interesses que constituem a sociedade pode se expressar e se realizar. Mas elas implicam também na tradição do que se designou como constitucionalismo, isto é, a necessidade de que princípios internalizados em instituições - como mecanismos de pesos e contrapesos - sejam garantidos por uma constituição legitimada pela sociedade, isto é, pela dimensão jurídico-legal que envolve valores compartilhados pela maioria dos membros da comunidade política. Embora essa visão faça referência a alguns conteúdos da democracia, é evidente que a sua ênfase mais importante são os procedimentos democráticos, cujo funcionamento depende da existência e do desempenho adequado de instituições específicas.

Uma perspectiva concorrente (e complementar) com as anteriores define a democracia em termos da sua qualidade, tornando explícito o foco nos conteúdos do regime democrático. Utilizando-se de uma analogia com o funcionamento do mercado, o conceito refere-se à qualidade do produto ou serviço produzido segundo procedimentos, conteúdos e resultados singulares. A qualidade envolve processos controlados por métodos e timing precisos, capazes de atribuir características específicas ao produto ou serviço, de modo a satisfazer as expectativas de seus consumidores potenciais. No caso da democracia, espera-se que esse regime seja capaz de satisfazer as expectativas dos cidadãos quanto à missão que eles atribuem aos governos (qualidade de resultados); confia-se que ele assegurará aos cidadãos e às suas associações o gozo de amplas liberdades e de igualdade políticas necessárias para que possam alcançar suas aspirações ou interesses (qualidade de conteúdo); e conta-se que suas instituições permitirão, por meio de eleições e de mecanismos de checks and balances, que os cidadãos avaliem e julguem o desempenho de governos e de representantes (qualidade de procedimentos). Instituições e procedimentos são vistos, neste caso, como meios de realização de princípios, conteúdos e resultados esperados pela sociedade do processo político que envolve a governança democrática. 
Com base nos pressupostos anteriores, Diamond e Morlino (2004) identificaram oito dimensões segundo as quais a qualidade da democracia pode variar. As cinco primeiras correspondem a regras de procedimentos, embora também sejam relativas ao seu conteúdo: o primado da lei, a participação e a competição políticas, e as modalidades de accountability (vertical, social e horizontal); as duas seguintes são essencialmente substantivas: de um lado, o respeito por liberdades civis e os direitos políticos e, de outro, como consequência do anterior, a progressiva implementação da igualdade política e de seus correlatos, como a igualdade social e econômica; por último, é mencionado um atributo que integra procedimentos a conteúdos, ou seja, a responsividade de governos e dos representantes, por meio do que os cidadãos podem avaliar e julgar se as políticas públicas, assim como o funcionamento prático do regime (leis, instituições, procedimentos e estrutura de gastos públicos) correspondem aos seus interesses e preferências. Embora esta perspectiva defina a democracia fundamentalmente em termos dos seus princípios e conteúdos mais importantes, fica claro que ela integra procedimentos institucionais e conteúdos, sem deixar de se referir aos resultados práticos do regime por meio do pressuposto de que a igualdade social e econômica pode ser alcançada se e quando a igualdade política seja efetiva.

Não obstante essas definições que focalizam procedimentos, princípios e conteúdos da democracia, uma terceira abordagem enfoca primordialmente a dimensão social do regime democrático, enfatizando a contraposição entre a sua substância e a sua formalidade, segundo a argumentação de autores que analisaram o processo de democratização de países pobres ou em vias de desenvolvimento. Ou seja, em acréscimo às noções que fazem referência aos direitos civis e políticos, as definições inspiradas nas tradições social-democrata, socialista e comunista européias tendem a incluir direitos sociais como serviços de saúde, educação, habitação, etc. na formulação do conceito; baseada na crítica marxista da estrutura assimétrica da sociedade de classes, essa perspectiva argumenta que, a menos que os membros da comunidade política tenham condições suficientes para atender às suas necessidades básicas de sobrevivência e expressão, os princípios de liberdade, igualdade e participação política são destituídos de significação para eles (HUBER, RUESCHEMEYER and STEPHENS, 1997). Por outro lado, Dalton, Shin e Jou (2007) observaram que a dimensão substantiva da democracia é enfatizada também pela perspectiva que tende a ver o apoio do público de massas ao regime democrático como uma consequência da demanda por níveis de vida identificados com aqueles vigentes nas sociedades industriais avançadas, cuja riqueza e afluência são associadas com a experiência da democracia consolidada e estável. A ideia é que as respostas positivas a respeito da democracia pressupõem que, junto com a instalação do regime, vem o advento de níveis elevados de renda e de consumo. Neste caso, longe de considerações sobre 
os procedimentos institucionais ou os princípios fundamentais do sistema democrático, as percepções do público estariam conformadas por uma perspectiva essencialmente instrumental da democracia.

É evidente que, ao responder espontaneamente aos pesquisadores, os públicos de massas podem dar outras respostas às perguntas sobre a democracia, mas as perspectivas mencionadas acima, além de ser parte constitutiva do debate público contemporâneo, referem-se a escolhas substantivas que aparecem nos resultados de diferentes pesquisas internacionais sobre o assunto. Nesse sentido, as três abordagens mencionadas oferecem um enquadramento analítico útil para o exame dos níveis de apoio dos cidadãos ao regime democrático, mesmo a correspondência entre essas abordagens e as respostas dos entrevistados não sendo mecânica. Cada alternativa tem, de fato, implicações diferentes para a interpretação do apoio da opinião pública aos regimes resultantes dos processos de democratização das últimas três décadas. Por isso, neste estudo, considerou-se que elas oferecem uma base útil para a análise dos dados empíricos.

\section{Opiniões e atitudes sobre a democracia}

Na tradição brasileira de estudos de cultura política, as opiniões e as atitudes quanto ao regime democrático têm sido medidas preferencialmente por estímulos nominais diretos, isto é, por perguntas fechadas ou estruturadas que mencionam a palavra democracia. A alternativa mais comum usada no país (MOISÉS, 1995; MENEGUELLO, 2007) é a utilizada também na Europa e na América Latina (neste caso, pelo Consórcio Latinobarometro), e leva em conta a memória do público dos regimes autoritário e democrático com o objetivo de captar, ao mesmo tempo, a escolha por um deles ou a indiferença dos entrevistados diante de alternativas que se referem a diferentes experiências históricas e legados político-culturais. É um teste, portanto, de envolvimento político e de preferência entre alternativas políticas antitéticas. A formulação usual da pergunta é a seguinte:

"Com qual dessas três afirmações você concorda mais?

- A democracia é sempre melhor do que qualquer outra forma de governo;

- Em certas circunstâncias, é melhor uma ditadura do que um regime democrático;

- Tanto faz se o governo é uma democracia ou uma ditadura".

Os dados da Tabela 2 apresentam os resultados para os anos em que a pergunta foi incluída nas pesquisas relatadas. Dois aspectos mais importantes sobressaem desses resultados desde logo: por um lado, fica claro que em um período de quase 20 anos de experiência com o novo regime, independentemente de algumas oscilações, a preferência pela democracia cresceu aproximadamente 28 
pontos, ultrapassando a marca de $2 / 3$ do público, mesmo se se considerar que os resultados do survey de dezembro de 2006 foram provavelmente influenciados pela mobilização política das eleições presidenciais; de fato, observando-se os resultados do survey de junho de 2006, quando a campanha eleitoral ainda não havia mobilizado a opinião pública, a diferença a favor da preferência pela democracia em relação à pesquisa de 1989 é de 21 pontos, totalizando cerca de 2/3 dos entrevistados; em dezembro, no entanto, a diferença chegou perto de 30 pontos.

Tabela 2

Preferência por Regime Político no Brasil (\%) $1989-2006$

\begin{tabular}{|l|l|l|l|l|l|l|}
\hline & $1989[1]$ & $1990[2]$ & $1993[3]$ & $1997[4]$ & $2006[5]$ & $2006[6]$ \\
\hline Democracia & 43,6 & 54,7 & 57,9 & 56,1 & 64,8 & 71,4 \\
\hline Ditadura & 19,4 & 16,7 & 13,7 & 12,3 & 13,5 & 14,2 \\
\hline Indiferença & 21,3 & 17,1 & 13,7 & 16,9 & 16,9 & 6,9 \\
\hline NS/NR & 15,7 & 11,5 & 14,7 & 14,7 & 4,8 & 7,6 \\
\hline
\end{tabular}

Fonte: 1, 2 e 3: Pesquisas "Democratização e Cultura Política "; 4: Pesquisa "Cultura Política e Cidadania" (Fund. Perseu Abramo); 5: Pesquisa "A Desconfiança dos Cidadãos das Instituições Democráticas"; 6: Pesquisa "Estudo Eleitoral Brasileiro - ESEB" 2006.

O segundo aspecto a se ter em conta é mais relevante: o crescimento da preferência pela alternativa democrática ao longo do tempo se dá às expensas, principalmente, da opção de indiferença quanto ao regime político e de diminuição do contingente dos que não souberam ou preferiram não responder à pergunta: no primeiro caso, a escolha da alternativa "Tanto faz a democracia ou a ditadura" diminui mais de três vezes, enquanto no segundo, os que antes não tinham condições de responder caem pela metade. Por outras palavras, embora o percentual dos que preferem o autoritarismo tenha se mantido em torno de $15 \%$ por todo o período, na resposta ao estímulo nominal direto a maioria absoluta dos brasileiros escolheu a democracia. A se levar em conta as teorias originárias de cultura política (ALMOND e VERBA, 1965), este fato seria indicador de que no Brasil as estruturas do regime democrático tornaram-se, no período considerado, congruentes com os valores e as orientações majoritárias na sociedade. Mas pesquisas anteriores mostraram que a cultura política dos brasileiros começou a se transformar mesmo antes da mudança do regime político, sob influência de fatores econômicos, sociais, políticos e culturais: a modernização da sociedade, sob impulso do crescimento econômico dos anos 1960 e início dos 1970, a experiência generalizada de terror do Estado e a sobrevivência contraditória de um sistema eleitoral semi-competitivo durante todo o regime autoritário (MOISÉS, 1995). 
Autores como Inglehart e Welzel (2005) sustentam que a cultura política tem grande capacidade de duração no tempo, mas admitem que ela se transforma sob o impacto dos efeitos da modernização e do próprio processo político. Para eles, o fator determinante de mudança das convicções políticas está associado com a emergência de valores pós-materialistas. No entanto, os processos de democratização do Brasil e de outros países latino-americanos, do mesmo modo que de africanos, apontam para uma direção diferente: mesmo nações que não se modernizaram ou que conheceram processos incompletos de modernização - como é o caso de vários países latino-americanos - passaram pela mudança dos valores políticos de seus cidadãos antes ou durante os processos de transição e consolidação políticas. A mobilização e a politização da sociedade civil jogaram papel importante para isso. Ou seja, a cultura política foi um fator importante, mesmo que isso não tenha significado a emergência generalizada de valores pósmaterialistas, indicando assim que ela muda ao longo do tempo sob efeito de condições que envolvem transformações econômicas e sociais e mobilização da sociedade.

Alguns autores argumentam, no entanto, que pesquisas realizadas com perguntas diretas sobre a democracia podem não revelar as efetivas opiniões e atitudes dos entrevistados que, em face da crescente difusão mundial de valores democráticos que se seguiu à queda do Muro de Berlim, tenderiam a responder positivamente à indagação sobre a preferência por regimes políticos ${ }^{4}$. Por causa das implicações metodológicas desses argumentos, as pesquisas mencionadas incluíram nos questionários, em ordem de apresentação destinada a evitar a influência de uma questão sobre a outra, estímulos relativos a atitudes antidemocráticas sem fazer menção direta ao termo democracia, de modo a permitir que convicções diferentes da formulação nominal direta viessem à tona. Os resultados dessas perguntas são comparados no Gráfico 1 com os índices de adesão nominal à democracia. Todos os indicadores crescem ao longo do tempo, mas a rejeição à volta dos militares ao poder, assim como o apoio a um sistema de partido único são significativos. Apesar disso, registrou-se um leve declínio de ambas as tendências em 1993, imediatamente após a grave crise política que resultou no impeachment do ex-presidente Collor de Mello; isso poderia indicar uma restrição quanto à efetividade da adesão à democracia ou mesmo uma atenuação

\footnotetext{
${ }^{4}$ Em sentido semelhante, Porto, em um artigo de 2000, argumentou que o uso da pergunta mencionada acima produziria resultados espúrios, "pois as pessoas teriam que optar entre dois extremos: democracia ou ditadura", e a preferência pela primeira alternativa expressaria a adesão pelo lado "correto" da vida. Ele desconsiderou, no entanto, o fato de a pergunta oferecer uma terceira alternativa, "Tanto faz se o governo é uma democracia ou uma ditadura", além de os entrevistados poderem dizer que não sabiam ou não queriam responder. Por outro lado, em contradição com a sua crítica de 2000, 0 próprio Porto se baseou na mesma pergunta, em um texto de 2004, para discutir o grau de apoio difuso à democracia em 17 países latino-americanos com base em dados do Latinobarometro (PORTO, 2000; 2004).
} 
da memória crítica em relação ao período do autoritarismo, mas na pesquisa daquele ano a preferência pelo regime democrático cresceu levemente, indicando que, mesmo divididos em face de uma situação crítica para o novo regime, os brasileiros confirmaram a sua escolha democrática anterior à crise.

\section{Gráfico 1}

\section{Preferência pela democracia, rejeição a governo militar e a partido único (\%)}

\section{Brasil}

1989-2006

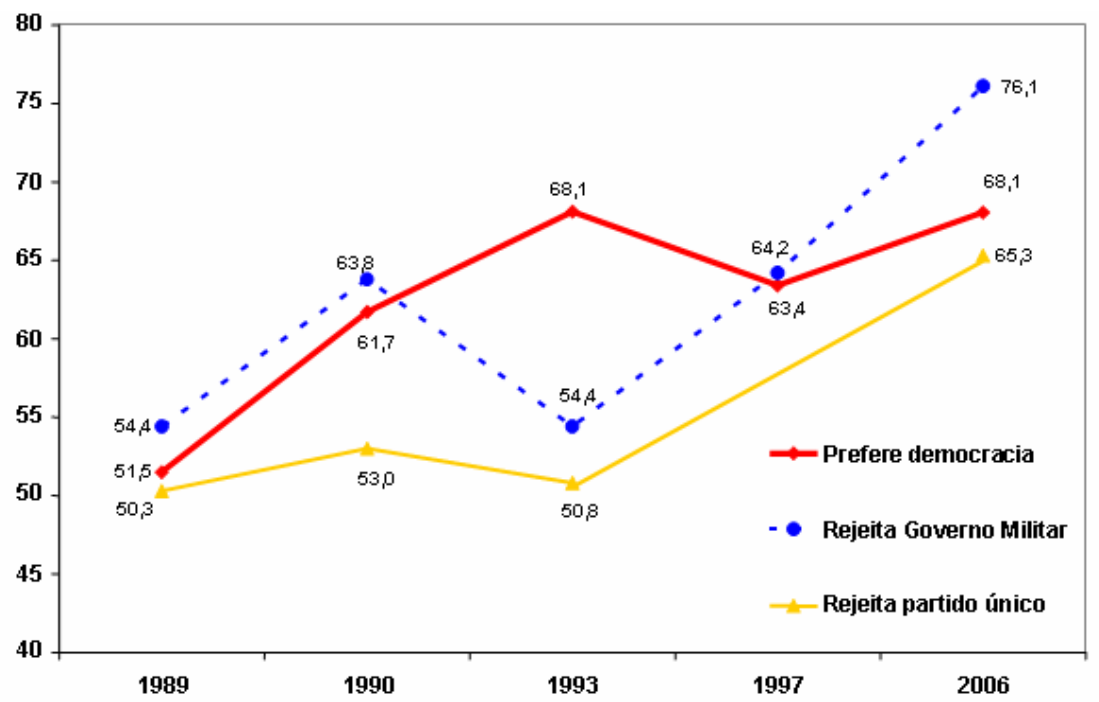

Fontes: Pesquisas "Democratização e Cultura Política": 1989, 1990 e 1993; "Cultura e Cidadania": 1997;" “A Desconfiança dos Cidadãos das Instituições Democráticas, 2006

Ainda com o objetivo de testar a efetividade da adesão à democracia, foram incluídas nos surveys perguntas sobre a concordância dos entrevistados quanto a ações que o Estado poderia adotar em face de conflitos sociais e políticos típicos das sociedades complexas e desiguais. As perguntas abordaram ações adotadas por governos militares ou não envolvendo a quebra da legalidade democrática. A ideia foi oferecer um estímulo antitético capaz de oferecer parâmetros para avaliação da consistência das convicções reveladas pelas respostas aos estímulos nominais diretos. Os dados da Tabela 3 revelam que, para cinco alternativas apresentadas sem menção à palavra democracia, a maioria dos entrevistados rejeitou a possibilidade de os governos adotarem ações antidemocráticas, embora, no caso de conflito entre trabalhadores e empresários, a aceitação de proibição do direito de greve tenha passado de 32 para 50\% em 17 anos. Nos outros casos, apenas $1 / 4$ ou menos dos entrevistados concordaram que o governo pode intervir em sindicatos, proibir a existência de algum partido político, censurar os meios de 
comunicação ou fechar o Congresso Nacional, confirmando a predominância das orientações democráticas sobre as autoritárias. Ainda que os patamares sejam ligeiramente superiores aos índices de indicadores diretos de preferência por um regime autoritário, a tendência geral segue o sentido esperado. Duas observações, no entanto, são necessárias: quanto ao direito de greve, é provável que a diminuição da rejeição dos democratas em autorizar os governos a adotarem medidas que proíbam os movimentos grevistas, mais do que uma recusa do direito em si, esteja ligada à percepção dos efeitos do aumento do número de greves semi-legais que afetaram serviços públicos fundamentais ao longo das últimas décadas. De fato, ainda que o direito de greve seja garantido pela Constituição de 1988, do mesmo modo como ocorreu após a Constituinte de 1946, o seu exercício não foi regulamentado pelo Congresso Nacional, deixando em aberto a possibilidade de que profissionais dos serviços públicos de saúde, educação, segurança e previdência social, para não falar de bancos e outros serviços públicos, paralisem as suas atividades a qualquer tempo, mesmo contrariando determinações da Justiça do Trabalho e, assim, prejudicando o atendimento à população. Nessas circunstâncias, a aceitação da alternativa que autoriza em tese os governos a agirem contra os movimentos grevistas pode expressar uma demanda por regulação das condições de ocorrência do conflito no sistema democrático. 
Tabela 3

Ações que o governo poderia tomar em situações de conflito social e político (\%) $1989 / 2002$

\begin{tabular}{|c|c|c|c|c|c|c|c|}
\hline Tipos de ações & & $\begin{array}{c}\text { Set. } 1989 \\
(1)\end{array}$ & $\begin{array}{c}\text { Dez. } 1989 \\
\text { (2) }\end{array}$ & $\begin{array}{c}1990 \\
(3)\end{array}$ & $\begin{array}{c}1993 \\
(4)\end{array}$ & $\begin{array}{c}1997 \\
(5)\end{array}$ & $\begin{array}{c}2002 \\
(6)\end{array}$ \\
\hline \multirow[b]{3}{*}{ Proibir greves } & Sim & 32,5 & 33,3 & 26,5 & 28,3 & 28,6 & 49,7 \\
\hline & Não & 55,1 & 50,8 & 60,8 & 67,5 & 64,5 & 47,3 \\
\hline & NS/NR & 12,5 & 15,9 & 12,7 & 4,1 & 6,9 & 2,9 \\
\hline \multirow{3}{*}{$\begin{array}{l}\text { Intervir em } \\
\text { sindicatos }\end{array}$} & Sim & 28,2 & 27,0 & $\cdot$ & 25,5 & 26,0 & - \\
\hline & Não & 57,7 & 50,4 & . & 65,3 & 59,5 & - \\
\hline & NS/NR & 14,0 & 22,6 & . & 9,1 & 14,4 & . \\
\hline \multirow{3}{*}{$\begin{array}{c}\text { Proibir a } \\
\text { existência de } \\
\text { algum partido }\end{array}$} & Sim & 19,5 & 17,5 & - & 24,5 & 18,2 & - \\
\hline & Não & 69,5 & 67,9 & - & 67,3 & 69,1 & - \\
\hline & NS/NR & 11,0 & 14,6 & - & 8,1 & 12,8 & . \\
\hline \multirow{3}{*}{$\begin{array}{l}\text { Censurar os } \\
\text { meios de } \\
\text { comunicação }\end{array}$} & Sim & 23,4 & 19,3 & - & 24,6 & - & 24,6 \\
\hline & Não & 64,8 & 64,9 & - & 68,3 & - & 67,3 \\
\hline & NS/NR & 11,8 & 15,8 & - & 7,0 & . & 8,0 \\
\hline \multirow{3}{*}{$\begin{array}{c}\text { Fechar o } \\
\text { Congresso } \\
\text { Nacional }\end{array}$} & Sim & 15,5 & 11,6 & - & 21,9 & 17,3 & . \\
\hline & Não & 68,6 & 70,3 & - & 66,4 & 64,0 & . \\
\hline & NS/NR & 15,9 & 18,0 & $\cdot$ & 11,6 & 18,8 & - \\
\hline \multirow[b]{3}{*}{ Proibir greves } & Sim & 32,5 & 33,3 & 26,5 & 28,3 & 28,6 & 49,7 \\
\hline & Não & 55,1 & 50,8 & 60,8 & 67,5 & 64,5 & 47,3 \\
\hline & NS/NR & 12,5 & 15,9 & 12,7 & 4,1 & 6,9 & 2,9 \\
\hline \multirow{3}{*}{$\begin{array}{l}\text { Intervir em } \\
\text { sindicatos }\end{array}$} & Sim & 28,2 & 27,0 & - & 25,5 & 26,0 & . \\
\hline & Não & 57,7 & 50,4 & . & 65,3 & 59,5 & - \\
\hline & NS/NR & 14,0 & 22,6 & . & 9,1 & 14,4 & . \\
\hline \multirow{3}{*}{$\begin{array}{c}\text { Proibir a } \\
\text { existência de } \\
\text { algum partido }\end{array}$} & Sim & 19,5 & 17,5 & - & 24,5 & 18,2 & - \\
\hline & Não & 69,5 & 67,9 & - & 67,3 & 69,1 & - \\
\hline & NS/NR & 11,0 & 14,6 & - & 8,1 & 12,8 & - \\
\hline \multirow{3}{*}{$\begin{array}{l}\text { Censurar os } \\
\text { meios de } \\
\text { comunicação }\end{array}$} & Sim & 23,4 & 19,3 & . & 24,6 & 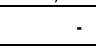 & 24,6 \\
\hline & Não & 64,8 & 64,9 & - & 68,3 & - & 67,3 \\
\hline & NS/NR & 11,8 & 15,8 & - & 7,0 & - & 8,0 \\
\hline \multirow{3}{*}{$\begin{array}{c}\text { Fechar o } \\
\text { Congresso } \\
\text { Nacional }\end{array}$} & Sim & 15,5 & 11,6 & - & 21,9 & 17,3 & . \\
\hline & Não & 68,6 & 70,3 & - & 66,4 & 64,0 & - \\
\hline & NS/NR & 15,9 & 18,0 & - & 11,6 & 18,8 & - \\
\hline
\end{tabular}

Fonte: 1, 2, 3, 4: Cultura Política e Democratização; 5: Fund. Perseu Abramo; 6: Eseb 2002.

A segunda observação é sobre o fato de que, ao longo dos quase vinte anos considerados, para quase todas as alternativas propostas a porcentagem dos que disseram que não sabiam ou não queriam responder diminuiu, indicando outra vez que o crescimento da rejeição de ações antidemocráticas se deu às expensas dessas categorias de respostas. Ou seja, ao longo do tempo, um contingente importante de respondentes que não sabia ou não queria se pronunciar sobre o papel do Estado quanto a importantes questões que afetam os direitos dos cidadãos tornou-se capaz de definir a sua preferência. 
A efetividade da adesão à democracia também transparece de outro tipo de dados: dois dos surveys realizados no período considerado incluíram questões fechadas que estimulavam os entrevistados a dizer a que princípios, direitos e valores eles associavam a noção de democracia. A ideia, neste caso, foi testar com a menção de elementos conceituais mais estruturados a percepção do público quanto a diferentes dimensões do regime democrático. Os dados da Tabela 4 chamam a atenção para alguns aspectos importantes: em primeiro lugar, nas duas pesquisas - separadas por um período de 13 anos - todas as porcentagens de respostas "tem muito a ver" e "tem a ver" para os conteúdos da democracia cresceram entre 7 e 32 pontos, com exceção daquele que associa a democracia com a igualdade de direitos para as mulheres, que teve $1,5 \%$ a menos na segunda pesquisa; por outro lado, nos dois anos os conteúdos mais associados com a democracia foram o direito de escolher governos através de eleições, as liberdades de organização e de expressão e a ideia de que cabe aos governos atender às necessidades de emprego, saúde, educação, etc. Com efeito, entre 1993 e 2006, as alternativas que mais cresceram na preferência estimulada dos respondentes foram as relativas às liberdades em questões morais e sexuais (31,9\% a mais), o combate à corrupção e ao tráfico de influência nos governos (31,5\% a mais), o princípio de igualdade social (26,1\% a mais), a ideia de que os governos devem ser fiscalizados pelo Congresso Nacional e pelo poder judiciário (24,5\% a mais) e o primado da lei $(21,3 \%)$. Todas essas alternativas estão relacionadas com a perspectiva da qualidade da democracia, referindo-se ao primado da lei, aos princípios de liberdade e igualdade, e aos procedimentos destinados a tornar efetiva a responsabilização dos governos. Ou seja, os indicadores mostram como os cidadãos conceituam o regime democrático quando são estimulados a fazer isso. Nos treze anos entre uma pesquisa e outra, os porcentuais dos que não sabiam ou não queriam responder às perguntas diminuíram entre 6 e 11\%, tendo caído mais para os que identificaram a democracia com o combate à corrupção e ao tráfico de influência (10,8\%). Mesmo admitindo-se que a crise do mensalão, entre 2005 e 2006, tenha influenciado as respostas sobre esse aspecto, não se pode desconsiderar o fato de que, já em 1993, 50\% dos respondentes identificavam a democracia com o combate a práticas políticas contra o patrimônio público; ou seja, esses elementos formam as visões do público a respeito do regime. Controlar a corrupção é uma função dos mecanismos de accountability que, por sua vez, são centrais para o conceito de qualidade da democracia. 
Tabela 4

Conteúdos Associados com a Democracia - resposta estimulada (\%) 1993 - 2006

\begin{tabular}{|l|c|c|c|c|c|c|c|c|c|c|}
\hline & \multicolumn{3}{|c|}{1993 (1) } & \multicolumn{3}{|c|}{ 2006 (2) } \\
\hline $\begin{array}{l}\text { Você acha que a } \\
\text { democracia tem a } \\
\text { ver com }\end{array}$ & $\begin{array}{c}\text { Muito } \\
\text { a ver }\end{array}$ & $\begin{array}{c}\text { Tem a } \\
\text { ver }\end{array}$ & $\begin{array}{c}\text { Pouco } \\
\text { a ver }\end{array}$ & $\begin{array}{c}\text { Não } \\
\text { tem a } \\
\text { ver }\end{array}$ & NS/NR & $\begin{array}{c}\text { Muito } \\
\text { a ver }\end{array}$ & $\begin{array}{c}\text { Tem } \\
\text { a ver }\end{array}$ & $\begin{array}{c}\text { Pouco } \\
\text { a ver }\end{array}$ & $\begin{array}{c}\text { Não } \\
\text { ta ver }\end{array}$ & $\begin{array}{c}\text { NS/N } \\
\text { R }\end{array}$ \\
\hline $\begin{array}{l}\text { Direito de escolher } \\
\text { o governo através } \\
\text { de eleições }\end{array}$ & 57,1 & 21,3 & 8,1 & 5,2 & 8,3 & 57,6 & 31,9 & 3,7 & 4,9 & 1,9 \\
\hline $\begin{array}{l}\text { Liberdades } \\
\text { políticas de } \\
\text { organização e } \\
\text { expressão (sind., } \\
\text { movimentos, etc.) }\end{array}$ & 44,8 & 20,5 & 15,4 & 6,7 & 12,5 & 48,2 & 35,1 & 7,3 & 5,9 & 3,5 \\
\hline $\begin{array}{l}\text { Igualdade social } \\
\text { Igualdade perante } \\
\text { a lei }\end{array}$ & 36,7 & 18,7 & 19,1 & 12,8 & 12,6 & 50,8 & 30,7 & 8,4 & 7,0 & 3 \\
\hline $\begin{array}{l}\text { Fiscalização do } \\
\text { governo p/ } \\
\text { Congresso } \\
\text { e Tribunais de } \\
\text { Justiça }\end{array}$ & 41,9 & 18,4 & 16,1 & 12,2 & 11,4 & 51,9 & 29,7 & 8,6 & 6,8 & 2,9 \\
\hline $\begin{array}{l}\text { Menos corrupção e } \\
\text { tráfico de } \\
\text { influência }\end{array}$ & 35,6 & 16,9 & 21,2 & 11,4 & 14,9 & 45 & 32 & 10,6 & 7,8 & 4,6 \\
\hline $\begin{array}{l}\text { Governo como } \\
\text { provedor de saúde, } \\
\text { emprego, } \\
\text { educação, etc }\end{array}$ & 35,3 & 14,5 & 15,9 & 19,3 & 15,0 & 40,3 & 31,2 & 10,5 & 13,8 & 4,2 \\
\hline $\begin{array}{l}\text { Igualdade de } \\
\text { direitos p/ as } \\
\text { mulheres }\end{array}$ & 49,1 & 20,1 & 13,4 & 7,5 & 9,9 & 55,6 & 32,3 & 5,3 & 4,4 & 2,3 \\
\hline $\begin{array}{l}\text { Liberdade em } \\
\text { questões morais e } \\
\text { sexuais }\end{array}$ & 33,9 & 15,9 & 17,5 & 18,3 & 14,5 & 44,3 & 33,4 & 9,4 & 8,5 & 4,4 \\
\hline
\end{tabular}

Fonte: 1: Cultura Política e Democratização; 2: A Desconfiança das Instituições Democráticas 


\section{A democracia nas palavras dos brasileiros}

Em que pesem os resultados apresentados acima, a validade de pesquisas que se referem diretamente ao conceito de democracia continua sendo objeto de controvérsia. Em vista disso, com o objetivo de oferecer uma nova alternativa para o exame da questão, o estudo voltou-se para os significados atribuídos pelos brasileiros à democracia em suas próprias palavras, ou seja, analisou as respostas à pergunta aberta sobre o assunto incluída nos questionários aplicados no período. A vantagem do uso de perguntas abertas em pesquisas de opinião é conhecida: elas solicitam e garantem, ao mesmo tempo, que os respondentes definam conceitos, categorias e situações de vida em seus próprios termos, mobilizando a sua familiaridade e o seu repertório verbal a respeito do assunto com base em sua experiência e cognição políticas. Trata-se de um teste rigoroso de captação da opinião dos entrevistados que é complementar e confirmatório da metodologia usual baseada em perguntas fechadas ou estruturadas sobre termos como democracia e outros.

Ambos os procedimentos de mensuração foram utilizados neste estudo. No caso das respostas à pergunta aberta sobre o significado da democracia, elas foram codificadas de modo a contemplar as três perspectivas discutidas em seções anteriores, ou seja, princípios/liberdades, procedimentos/instituições e dimensão social e, na prática, o procedimento mostrou que elas incluíam a maior parte das respostas dadas, para alem das inconsistentes. Princípios e liberdades incluem, neste caso, menções a liberdades políticas, liberdade de organização e de expressão, liberdade de participação, direito de ir e vir e outros correlatos; procedimentos e instituições incluem menções a governo do povo, direito de voto, eleições livres, direito de escolher governo, regra de maioria, representação política, acesso à justiça e fiscalização e controle de governos; dimensão social inclui igualdade social, acesso a serviços de saúde, educação, habitação, emprego, salários justos e desenvolvimento econômico; e, finalmente, as respostas inconsistentes envolveram menções como "a democracia é boa", "é governo honesto", "é corrupção", "é governo de brigas" e semelhantes (vide Anexo 1 com a lista completa de menções). Os resultados da codificação indicada são apresentados no Gráfico 2. 


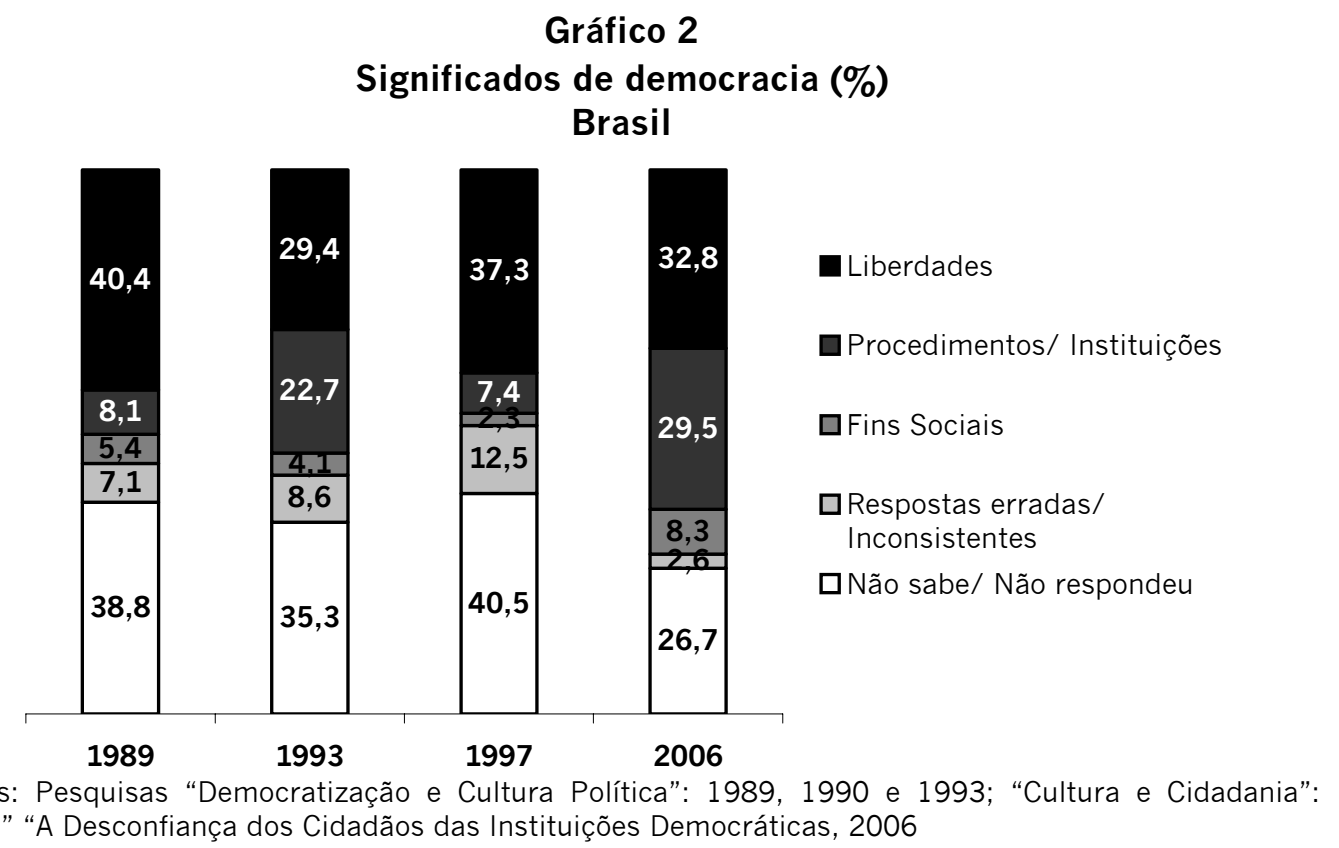

Os dados revelam que, entre 1989 e 2006, a maior parte dos brasileiros consultados foi capaz de definir a democracia nos termos discutidos antes; de fato, $54 \%$ fizeram isso em 1989, 65\% quatro anos mais tarde, 47\% em 1997 e quase $71 \%$ em 2006; ou seja, entre o primeiro e o último survey a diferença é de quase 18 pontos para mais, em que pese a tendência ter oscilado para baixo em 1997, quando nada menos que $53 \%$ dos entrevistados não souberam responder a pergunta ou ofereceram respostas inconsistentes. Em suas respostas espontâneas, mais de $32 \%$ definiram a democracia em termos dos princípios de liberdade e direitos correlatos em 2006. O contingente dos que definiram a democracia assim era superior a $40 \%$ no início do período, provavelmente refletindo a percepção de falta de liberdade durante o regime militar, mas nos anos seguintes a taxa se estabilizou em cerca de $1 / 3$ do público pesquisado. Os dados também mostram que um contingente de entrevistados quase igual ao anterior definiu a democracia em termos de procedimentos e instituições na última pesquisa, chamando a atenção ainda o fato de que, embora essa escolha oscile ao longo do período, ela cresce no último ano considerado, totalizando cerca $30 \%$ do público que, a esta altura, tinha passado por vários anos de experiência com o funcionamento relativamente estável das instituições democráticas. Surpreendentemente, no entanto, levando-se em consideração o peso das desigualdades sociais e econômicas para a maior parte da população brasileira, a alternativa que recebeu a menor taxa de preferência dos entrevistados nas quatro pesquisas é a que se refere à dimensão social; assim, ao final do período analisado, quando a taxa alcança o 
seu patamar mais elevado, apenas 8 em cada 100 brasileiros definiram a democracia em termos de objetivos substantivos, o que coloca em questão a hipótese segundo a qual as pessoas comuns preferem a democracia porque identificam esse regime apenas com o atendimentos de suas necessidades sociais; em realidade, as análises relatada a seguir mostram que, sem descartar completamente esses objetivos, os indivíduos definem preferencialmente a democracia em termos de princípios, conteúdos e procedimentos.

Outro achado importante desse exame preliminar dos dados é que, somadas as respostas inconsistentes com as dos que não sabem ou não respondem à pergunta, o volume de brasileiros incapazes de definir a democracia diminuiu ao longo do tempo: eles eram cerca de 46\% em 1989 e são menos de 30\% em 2006. De fato, o número de entrevistados que responde de modo inconsistente cai de 7 em cada 100, em 1989, para menos de 3 em 2006, o que contraria uma observação de Dalton, Shin e Jou (2007) sobre o Brasil em seu artigo sobre o tema ${ }^{5}$. Por outras palavras, no último ano do período considerado, depois do regime democrático ter completado cerca de duas décadas de existência no país, mais de $70 \%$ dos entrevistados brasileiros foram capazes de oferecer respostas consistentes sobre o significado da democracia, uma proporção comparável à encontrada em alguns países de democracia consolidada e em países do Leste Europeu, como o estudo dos autores citados acima indica. Mas a grande novidade dos dados sobre o Brasil está no fato de a maior parte dos indivíduos consultados definirem o regime em termos de dois dos mais importantes componentes do processo democrático, isto é, as liberdades e os procedimentos institucionais criados para defendê-las e para realizar os seus corolários. Isso evidencia que, ao contrário das suposições dos céticos e de parte da literatura, para a maioria dos brasileiros a democracia não é apenas "lip service", ou seja, a suposta repetição do lado "correto" da vida, mas algo que se refere a aspectos fundamentais da sua experiência política recente.

Uma interpretação usual desses resultados baseia-se na premissa de teorias institucionalistas segundo a qual a adesão dos cidadãos à democracia decorre precisamente da sua experiência com esse regime, ou seja, que a sua continuidade no tempo levaria as pessoas comuns a se habituarem às suas vantagens e a aderirem a valores democráticos como princípios, liberdades e seus procedimentos institucionais (RUSTOW, 1970). Outros autores, no entanto, enfatizam o efeito dos

\footnotetext{
${ }^{5}$ Dalton, Shin e Jou (2007, p. 7), depois de analisarem a série histórica de dados do Latinobarometro dos últimos dez anos, observaram que a maioria dos brasileiros, em 2001, não foi capaz de dar uma resposta à pergunta sobre a democracia e acrescentaram que, em vários outros países da América Latina, os entrevistados se caracterizam por níveis baixos de consciência democrática. Os dados das minhas pesquisas desconfirmam esse diagnóstico para o Brasil, e uma explicação possível refere-se ao fato de o Latinobarometro não ter usado amostras representativas em todos os anos pesquisados, envolvendo amostras reduzidas ao público das capitais de Estados em algumas pesquisas no Brasil.
} 
valores sobre as instituições em decorrência da modernização das estruturas econômicas e sociais, com implicações para o papel da escolaridade e dos meios de comunicação de massa (INGLEHART e WELZEL, 2005). Com efeito, adotando uma perspectiva probabilística em contraposição às abordagens deterministas, esses autores ressaltam a importância da cultura política para explicar o crescimento da preferência pela democracia. Em vista de que o atendimento de ensino fundamental no país ultrapassou a marca dos 95\%, nos anos 1990 , e de que mais de $90 \%$ da população brasileira tem acesso à televisão, esses aspectos foram incluídos na análise. A premissa adotada neste artigo, no entanto, não considera essas alternativas contraditórias, mas complementares como o autor argumentou em outra ocasião (MOISÉS, 2008b). Além disso, pesquisas anteriores mostraram que a percepção da democracia pelo público se desdobra em duas dimensões, uma baseada em valores e ideais, e outra apoiada em sua expressão prática; no primeiro caso, a dimensão da cultura e dos valores políticos é importante; no segundo, o papel das instituições e do seu desempenho é decisivo para definir como os cidadãos percebem o regime (SHIN, 2005; MOISÉS, 2007). Na perspectiva da qualidade da democracia, as duas dimensões são relevantes porque enquanto a primeira se refere aos conteúdos e princípios fundamentais do regime, a segunda diz respeito aos meios através dos quais aqueles conteúdos se tornam efetivos; mas essas dimensões têm expressão e mensuração empíricas distintas. As respostas dos brasileiros às perguntas estruturadas sobre a democracia, assim como à pergunta aberta sugerem que para eles princípios como a liberdade ou os procedimentos democráticos tomados isoladamente são insuficientes para definir o conceito: a democracia significa mais do que essas partes, e este significado está relacionado tanto a aspectos que afetam a capacidade dos indivíduos de controlar a sua própria vida - através do gozo da liberdade -, como os procedimentos através dos quais isso se torna possível pelo desempenho das instituições. Em certo sentido, é como se os brasileiros estivessem sugerindo, em suas próprias palavras, que forma e conteúdo não podem ser separados na consideração sobre o significado da democracia, pois ambos fazem parte do mesmo processo.

Os testes de associação relatados na Tabela 5 oferecem uma primeira aproximação com a questão. As associações apresentadas entre a variável formada pelos que souberam responder o que é a democracia - com base na soma dos que mencionaram as dimensões de liberdades, procedimentos e fins sociais - com indicadores sócio-demográficos, de cultura política, confiança interpessoal e institucional, memória política, avaliação do funcionamento do regime e de suas instituições, são as que se mostraram significantes ao nível de 0,01 e 0,05. As variáveis usadas no teste são binárias, a exemplo da preferência pela democracia, cuja escolha é tomada aqui em contraposição a todos os que preferiram outras opções (vide relação completa de variáveis testadas no Anexo 2). 
Tabela 5

Associação entre 'sabe o que é democracia' e indicadores atitudinais

\begin{tabular}{|c|c|}
\hline Variáveis Sociodemográficas & $\begin{array}{c}\text { Coef. de } \\
\text { contingência }\end{array}$ \\
\hline Renda mensal familiar (baixa - até $\mathrm{R} \$ 780,00$ ) & .086 \\
\hline Idade (acima de 39 anos) & .059 \\
\hline Regiões (Sul e Sudeste) & .059 \\
\hline Sexo masculino & .089 \\
\hline Escolaridade (baixa: analfabetos e até colegial incompleto) & .195 \\
\hline \multicolumn{2}{|l|}{ Democracia } \\
\hline Preferência por regime: democracia & .171 \\
\hline Democracia $=$ direito de escolher governo & .185 \\
\hline Democracia $=$ liberdades políticas & .150 \\
\hline Democracia $=$ igualdade social & .135 \\
\hline Democracia $=$ igualdade perante a lei & .161 \\
\hline Democracia $=$ fiscalização do governo pelo Congresso & .130 \\
\hline Democracia = controle da corrupção e do tráfico de influência & .069 \\
\hline Democracia= educação, saúde, emprego, etc. & .133 \\
\hline $\begin{array}{l}\text { Democracia = fiscalização do governo pelo Ministério Público e } \\
\text { Justiça }\end{array}$ & .141 \\
\hline Democracia $=$ igualdade de direitos para as mulheres & .105 \\
\hline Democracia = liberdades em questões morais e sexuais & .131 \\
\hline Democracia = multipartidarismo & .114 \\
\hline Partidos são indispensáveis à democracia & .125 \\
\hline Presidente pode tomar decisões sem ouvir o Congresso & .075 \\
\hline O país funcionaria melhor se os militares voltassem ao poder & .164 \\
\hline O Brasil seria melhor se existisse apenas um partido político & .155 \\
\hline Só uma ditadura daria jeito no Brasil & .130 \\
\hline \multicolumn{2}{|l|}{ Cidadania } \\
\hline Votaria mesmo que o voto não fosse obrigatório & .133 \\
\hline Existe igualdade perante a lei & .058 \\
\hline As leis trabalhistas protegem os cidadãos & .065 \\
\hline Entrevistados não compreendem a política & .069 \\
\hline Prestam atenção a notícias políticas na TV & .149 \\
\hline Têm interesse por política & .181 \\
\hline \multicolumn{2}{|l|}{ Confiança } \\
\hline Confiança interpessoal & .062 \\
\hline \multicolumn{2}{|l|}{ Avaliação / Satisfação } \\
\hline As eleições no Brasil são limpas e honestas & .083 \\
\hline Apesar de problemas, democracia é a melhor forma de governo & .081 \\
\hline
\end{tabular}


Os dados indicam que, além da escolaridade, existe associação entre as respostas de quem sabe o que é a democracia e diferentes indicadores atitudinais como preferência pelo regime e aos conteúdos da democracia, valores políticos, interesse por política, participação eleitoral, percepções da cidadania e atenção às informações políticas através da televisão. Vários indicadores de avaliação de desempenho do regime ou de governos incluídos na análise não se mostraram significantes, a exemplo da satisfação com a democracia, avaliação da economia e outros (excluídos da Tabela 5). Os poucos indicadores de avaliação do regime que são significantes apresentaram, no entanto, coeficientes de associação muito baixos. Os resultados sugerem que a opinião dos que sabem o que é a democracia se associa tanto com indicadores de cultura política e valores políticos como de percepção sobre o papel reservado às instituições democráticas. Esses resultados são parcialmente diferentes dos que foram encontrados por Meneguello (2007) em um estudo sobre as bases da adesão democrática no Brasil entre 2002 e 2006, em que a avaliação do governo de Luiz Inácio Lula da Silva e da situação econômica surgiram como fatores explicativos daquela adesão. Alguns testes apresentados a seguir retomam a questão a partir do ângulo adotado neste capítulo.

\section{Fatores associados com a definição de democracia}

Uma análise fatorial da variável formada pelos que souberam responder a pergunta sobre a democracia e de outros indicadores (Tabela 6) foi feita em seguida (vide Anexo 3 para a relação completa das variáveis incluídas no modelo). 0 teste serviu para a averiguação do sentido de agregação de variáveis relativas a duas abordagens concorrentes, a institucionalista e a culturalista, a respeito das percepções do público sobre a democracia. 
Tabela 6

Fatores formadores das visões da democracia no Brasil- 2006

\begin{tabular}{|c|c|c|c|c|c|c|c|c|c|c|}
\hline \multicolumn{11}{|c|}{ Rotated Component Matrix(a) } \\
\hline & & & & & Comp & onent & & & & \\
\hline & 1 & 2 & 3 & 4 & 5 & 6 & 7 & 8 & 9 & 10 \\
\hline Significado de democracia & & & & &, 406 & & & & & \\
\hline $\begin{array}{l}\text { Atenção às notícias sobre } \\
\text { política na TV }\end{array}$ & & & & &, 681 & & & & & \\
\hline Confia na maioria das pessoas &, 304 & & & & & & & & & \\
\hline Confia no Poder Judiciário &, 718 & & & & & & & & & \\
\hline Confia no Congresso Nacional &, 794 & & & & & & & & & \\
\hline Confia nos Partidos Políticos &, 766 & & & & & & & & & \\
\hline Confia no Governo &, 661 & & & & & & & & & \\
\hline $\begin{array}{l}\text { Partidos Políticos são } \\
\text { necessários ao país }\end{array}$ & & &, 812 & & & & & & & \\
\hline $\begin{array}{l}\text { Deputados e Senadores são } \\
\text { necessários ao país }\end{array}$ & & &, 808 & & & & & & & \\
\hline $\begin{array}{l}\text { Tribunais de Justiça são } \\
\text { necessários ao país }\end{array}$ & & &, 733 & & & & & & & \\
\hline Orgulho de ser brasileiro & & & & & & & & & & ,746 \\
\hline Igualdade perante a lei & & & & & & & & &, 642 & \\
\hline Os brasileiros cumprem as leis & & & & & & & & &, 713 & \\
\hline A lei deve ser obedecida sempre & & & & ,388 & & & & & & \\
\hline $\begin{array}{l}\text { Sente-se protegido pelas leis } \\
\text { trabalhistas }\end{array}$ & & & & & & & & &, 453 & \\
\hline Viveria em outro país & & & & & & & & & & ,700 \\
\hline Satisfeito com a democracia & & & & & & & & &, 540 & \\
\hline $\begin{array}{l}\text { Democracia pode funcionar sem } \\
\text { partidos }\end{array}$ & & & & & & ,833 & & & & \\
\hline $\begin{array}{l}\text { Democracia pode funcionar sem } \\
\text { Congresso }\end{array}$ & & & & & &, 835 & & & & \\
\hline $\begin{array}{l}\text { Não importa que o governo } \\
\text { passe por cima de leis, } \\
\text { Congresso e instituições, em } \\
\text { situação de crise }\end{array}$ & & & & & & & & ,782 & & \\
\hline
\end{tabular}




\begin{tabular}{|c|c|c|c|c|c|c|c|}
\hline $\begin{array}{l}\text { Prefere a democracia a um líder } \\
\text { salvador que não seja } \\
\text { controlado pelas leis }\end{array}$ & & & & & & ,615 & \\
\hline $\begin{array}{l}\text { Em crise, o presidente pode } \\
\text { deixar de lado o Congresso e os } \\
\text { Partidos Políticos }\end{array}$ & & & & & & ,779 & \\
\hline $\begin{array}{l}\text { O país funcionaria melhor se os } \\
\text { militares voltassem ao poder }\end{array}$ & & & & & ,842 & & \\
\hline $\begin{array}{l}\text { Só uma ditadura pode dar jeito } \\
\text { no Brasil }\end{array}$ & & & & & ,842 & & \\
\hline $\begin{array}{l}\text { Avaliação positiva do governo } \\
\text { Lula }\end{array}$ & &, 756 & & & & & \\
\hline $\begin{array}{l}\text { Avaliação positiva da situação } \\
\text { econômica do país }\end{array}$ & &, 715 & & & & & \\
\hline Interessado por política & & &, 755 & & & & \\
\hline $\begin{array}{l}\text { Sente-se próximo aos partidos } \\
\text { políticos }\end{array}$ & & &, 532 & & & & \\
\hline $\begin{array}{l}\text { Os partidos são indispensáveis à } \\
\text { democracia }\end{array}$ & & & & ,394 & & & \\
\hline Votaria se não fosse obrigatório & &, 359 & & & & & \\
\hline $\begin{array}{l}\text { Avaliação positiva do Poder } \\
\text { Judiciário }\end{array}$ &, 633 & & & & & & \\
\hline $\begin{array}{l}\text { Avaliação positiva do Congresso } \\
\text { Nacional }\end{array}$ &, 826 & & & & & & \\
\hline $\begin{array}{l}\text { Avaliação positiva dos Partidos } \\
\text { Políticos }\end{array}$ &, 779 & & & & & & \\
\hline Avaliação positiva do Governo &, 609 & & & & & & \\
\hline
\end{tabular}

Fonte: "A Desconfiança dos Cidadãos das Instituições Democráticas”, 2006.

O modelo incluiu variáveis binárias relativas a valores, conteúdos e instituições da democracia - particularmente, relativas à participação eleitoral e os partidos - e variáveis de avaliação da política, do governo Lula e da economia do país $^{6}$. Com capacidade de explicação da variância acima de 54\%, a matriz resultante formou 10 fatores, o que sugere certa dispersão das categorias

\footnotetext{
${ }^{6}$ As variáveis incluídas no modelo são binárias; aquelas cujos pesos são maiores que .50 estão grafadas em negrito.
} 
analíticas: a) o primeiro fator ficou formado pelas variáveis de confiança em instituições (com peso entre .60 e .70) e confiança interpessoal (neste caso, com um peso bastante mais baixo, de .30); b) o segundo fator agrupou as variáveis de avaliação de instituições como o governo, partidos, congresso e o judiciário (com peso entre .60 e.80); c) o terceiro fator revelou a agregação de variáveis que se referem a instituições consideradas necessárias para que o país siga em frente, como partidos, o congresso e o poder judiciário (com peso variando entre $.70 \mathrm{e}$ .80); d) o quarto fator agrupou duas variáveis de avaliação, uma do governo Lula, e outra da economia do país e, além disso, uma variável sobre a submissão à lei e outra sobre a disposição de participação no processo eleitoral (enquanto as duas primeiras tiveram pesos em torno de .70, as duas últimas ficaram em torno de .30); e) o quinto fator foi formado pela variável relativa aos que sabem o que é a democracia e mais as variáveis de exposição à informação política através da televisão, o interesse pela política e proximidade com os partidos políticos (estas, com peso variando entre .50 e .70, enquanto a primeira ficou abaixo de .50); f) o sexto fator agregou duas variáveis sobre a necessidade de partidos e do Congresso para que a democracia possa existir (com peso superior a .80); g) o sétimo fator ficou formado por duas variáveis que expressam orientações autoritárias (com peso superior a .80); h) o oitavo fator agregou outras variáveis relativas à escolha entre o autoritarismo e a democracia (com peso entre .60 e .70); i) o nono fator mostrou que variáveis relativas à satisfação com a democracia, a percepção sobre o princípio de igualdade perante a lei, assim como de cumprimento da lei e proteção das leis trabalhistas estão juntas (com peso variando entre .50 e .70, mas a última não chegou a .50); j) finalmente, o último fator foi formado por duas variáveis relativas ao sentimento de pertencimento à comunidade política (com peso variando em torno de .70).

Algumas observações importantes derivam da análise apresentada. Prima faciae, as respostas dos entrevistados sobre a democracia se agregam apenas com a sua exposição às notícias sobre política na televisão, ao seu interesse geral por política e, de forma notável, à sua proximidade dos partidos políticos; em princípio, isso pareceria dar razão, por uma parte, às hipóteses que se referem ao efeito da difusão internacional da democracia, mas também à identificação deste regime com uma das mais importantes instituições de representação, isto é, o partido político. Chama a atenção ainda que fatores como confiança política, avaliação de instituições, escolha de instituições necessárias para o país seguir em frente e indicadores de pertencimento à comunidade política apareçam distribuídos em fatores distintos. Isto confirma as hipóteses de Pippa Norris (1999), baseadas na contribuição de David Easton (1963), de que o fenômeno de apoio político não pode ser considerado em bloco, mas tem de ser visto a partir da distinção de diferentes dimensões que funcionam com lógica própria, às vezes separando-as e outras 
indicando a existência de pontos de conexão entre elas. Esse parece ser o caso das dimensões que se referem à comunidade política, ao apoio a valores políticos e, finalmente, à avaliação do desempenho de governos e de instituições. Note-se ainda que a participação em eleições e o reconhecimento da importância de partidos, do parlamento e do judiciário estão agregados em um mesmo fator, mas aparecem separados de indicadores atitudinais semelhantes. Por outras palavras, enquanto há aparentemente mais coerência na percepção em torno de variáveis que envolvem as liberdades, a perspectiva a respeito dos procedimentos institucionais da democracia revela-se bastante mais dispersa. Meneguello (2007) também relatou alguma dispersão dos fatores institucionais ao tratar da adesão democrática no texto mencionado antes.

\section{Determinantes dos significados atribuídos à democracia}

Os resultados relatados até aqui mostram que, ao contrário das expectativas pessimistas, a maior parte dos entrevistados brasileiros tem ideias definidas sobre a democracia como um ideal, mas os testes anteriores não permitiram identificar os determinantes dessas convicções. Por essa razão, o passo seguinte do estudo consistiu na realização de uma análise de regressão logística da variável dependente formada pelas respostas dos que sabem o que é democracia e, como explicativas, um conjunto de indicadores sócio-demográficos, de cultura cívica, de confiança interpessoal, de participação política, de avaliação de instituições e de avaliação do desempenho do governo do dia (vide Anexo 4 para a relação completa de variáveis testadas). O procedimento teve por objetivo testar o efeito de indicadores associados com hipóteses concorrentes, ou seja, tanto com as sustentadas por este artigo, como as relativas ao papel da difusão internacional em torno da democracia, o efeito da modernização econômica e social, a influência do desempenho do governo - especialmente da economia -, a influência das crenças religiosas, do capital social e de diferentes modos de participação política. O modelo não é parcimonioso; o seu R quadrado ajustado está perto de .30. As linhas em negrito indicam as variáveis que não são significantes e que, portanto, descomprovam as hipóteses correspondentes discutidas pela literatura (Tabela 7). 
Tabela 7

Regressão logística de "sabe o que é democracia" - 2006

\begin{tabular}{|c|c|c|c|}
\hline VARIIÁVEIS EXPLICATIVAS & B & Sig. & $\operatorname{Exp}(B)$ \\
\hline Intercept & $-2,752$ & .000 & \\
\hline Homens & 0,298 & ,014 & 1,347 \\
\hline Escolaridade média ou mais & 0,651 & .000 & 1,917 \\
\hline Renda familiar + de R\$1.300 & 0,312 & ,071 & 1,366 \\
\hline Integra a PEA & 0,344 &, 006 & 1,410 \\
\hline Cidades + 500 mi habitantes & 0,022 & ,869 & 1,022 \\
\hline Regiões Sudeste e Sul & $-0,539$ & .000 & 0,583 \\
\hline Confiança interpessoal & 0,322 & ,025 & 1,380 \\
\hline Católicos & 0,109 & ,372 & 1,115 \\
\hline Brancos & 0,410 & ,001 & 1,507 \\
\hline Atenção às not. Políticas na TV & 0,423 & ,003 & 1,526 \\
\hline Tem interesse por política & 0,620 & ,001 & 1,859 \\
\hline $\begin{array}{l}\text { Gov. tem de respeitar leis e instituições, mesmo na } \\
\text { crise }\end{array}$ & 0,315 & ,007 & 1,371 \\
\hline Rejeita retorno dos militares & 0,688 & .000 & 1,990 \\
\hline Rejeita sist. De partido único & 0,507 & .000 & 1,661 \\
\hline Votaria se voto ñ fosse obrigat. & 0,264 & ,027 & 1,302 \\
\hline Conversa sobre política & 0,534 & ,001 & 1,706 \\
\hline Assinaria abaixo-assinado & 0,359 & ,005 & 1,432 \\
\hline Participaria de boicotes & 0,302 & ,047 & 1,353 \\
\hline Participa de grupo religioso & $-0,225$ &, 093 & 0,798 \\
\hline Existe igualdade perante a lei & $-0,273$ &, 054 & 0,761 \\
\hline Partidos representam população e eleitores & 0,271 & ,040 & 1,311 \\
\hline Eleições são limpas no Brasil & 0,321 &, 007 & 1,378 \\
\hline Gov. dev. intervir + na economia & 0,319 & 015 & 1,376 \\
\hline $\begin{array}{l}\text { Funcionários ñ levam em conta o q. cidadãos } \\
\text { pensam }\end{array}$ & 0,283 &, 061 & 1,327 \\
\hline $\begin{array}{l}\text { Órgãos públicos ñ prestam informações aos } \\
\text { cidadãos }\end{array}$ & 0,229 & ,046 & 1,257 \\
\hline Confia na policia & $-0,205$ & ,130 & 0,815 \\
\hline Confia no Congresso Nacional & 0,248 & ,095 & 1,282 \\
\hline Prefeituras são necessárias & $-0,290$ & ,126 & 0,748 \\
\hline Avalia bem habitação & $-0,259$ & ,033 & 0,772 \\
\hline Avalia bem previdência social & $-0,294$ & 023 & 0,745 \\
\hline Avalia bem transportes públicos & 0,411 & ,002 & 1,508 \\
\hline Corrupção é problema sério & 0,905 & 011 & 2,473 \\
\hline Políticos usam caixa dois em campanhas eleitorais & 0,511 & 007 & 1,666 \\
\hline Brasileiros usariam caixa dois (no lugar de políticos) & $-0,534$ & ,002 & 0,586 \\
\hline $\begin{array}{l}\text { Brasileiros faturariam obras públicas (no lugar de } \\
\text { políticos) }\end{array}$ & 0,369 &, 020 & 1,446 \\
\hline
\end{tabular}


MOISÉS, J. A. Os significados da democracia segundo os brasileiros.

\begin{tabular}{|l|r|r|r|}
\hline Sit. econômica familiar é boa & $-0,105$ &, 372 & 0,900 \\
\hline Votou em Lula em 2004 & $-0,176$ &, 146 & 0,839 \\
\hline Sit. econômica do país melhorou com Lula & $-0,108$ &, 382 & 0,898 \\
\hline
\end{tabular}

Fonte: "A Desconfiança dos Cidadãos das Instituições Democráticas", 2006

Nagelkerke R Square: .286; as variáveis do modelo são binárias.

No modelo adotado, os determinantes mais importantes das respostas capazes de definir a democracia em termos de liberdades, procedimentos institucionais e fins sociais são - pela ordem derivada dos coeficientes de significância e das odds ratio das variáveis explicativas - a percepção de que a corrupção é um problema sério (duas vezes e meia mais de chance), a rejeição ao retorno dos militares ao poder ( $99 \%$ mais de chance), a escolaridade de níveis médio e superior ( $91 \%$ a mais de chance), o interesse pela política ( $85 \%$ a mais de chance), o hábito de conversar com amigos a respeito (70\% mais chance), a rejeição a um sistema de partido único ( $66 \%$ mais chance) e a percepção pública de que os políticos brasileiros se utilizam do "caixa dois" em suas campanhas eleitorais (66\% mais de chance também). É notável, por outro lado, que diferente de suposições de parte da literatura especializada, na interação produzida pelas variáveis incluídas no modelo adotado, em comparação com os habitantes de cidades médias e pequenas, a variável correspondente à resposta dos habitantes das cidades de mais de 500 mil não interfere nos resultados, nem aquela relativa aos que têm renda familiar superior a $R \$ 1.300$ ao mês mostra-os como mais propensos a definir a democracia. Ou seja, controlando-se pelas demais variáveis, esses fatores não são definidores da capacidade das pessoas de responder à pergunta, essa possibilidade está espalhada entre os entrevistados de renda inferior e também entre os que vivem em cidades pequenas e médias, o que pode indicar que mudanças na cultura política dos brasileiros não dependem diretamente desses fatores. A percepção crítica de que os funcionários do governo não prestam a atenção ao que pensam os cidadãos não é significante, mas de que os órgãos públicos não dão as informações necessárias ao público sim ( $25 \%$ mais de chance). A confiança na polícia e no Congresso Nacional, a convicção de que as prefeituras são importantes, da mesma forma que as crenças religiosas não exercem influência para a definição da democracia; neste caso, aliás, os dados desconfirmam uma das hipóteses de Inglehart, segundo a qual o Brasil como parte da América Latina faria parte do mapa cultural caracterizado pela tradição ibérica e católica. Ser católico ou professar outra crença não influi nos resultados.

Os resultados mais surpreendentes, no entanto, referem-se às hipóteses a respeito da influência da avaliação positiva do desempenho do governo do dia, em especial, da situação da economia do país e da situação econômica da família dos entrevistados: nenhuma dessas variáveis se revelou significante no modelo rodado, nem mesmo aquela relativa ao voto no presidente Lula em 2002. Ou seja, diferente 
de uma das conclusões de Pippa Norris (1999), os vencedores do jogo político, no caso brasileiro, não são os mais propensos a saber definir a democracia. São os cidadãos críticos quanto ao desempenho das instituições no que se refere à corrupção e quanto a alguns serviços públicos, os que têm maior chance de saber o que é a democracia. Diferente, nesse sentido, de achados de Meneguello (2008), as variáveis de avaliação positiva dos resultados da ação do governo, pelo menos, no que se refere à economia do país ou ao governo de modo geral, não ajudam a explicar a variável dependente. Isso sugere que precisamos de mais pesquisa sobre a relação entre o desempenho de governos e da economia com os indicadores de adesão ou de preferência pela democracia.

Chama a atenção ainda que, com odds ratio mais próximas de 1 , entre as variáveis sócio-demográficas, estar integrado à população economicamente ativa (41\% mais de chance) ou pertencer ao sexo masculino (34\% a mais) são indicadores de capacidade de responder à pergunta; entre as variáveis de cultura política, ser branco ( $50 \%$ mais de chance), prestar a atenção às notícias políticas na TV (52\% mais), confiar na maioria das pessoas ( $38 \%$ mais) e acreditar que o governo não está autorizado a desrespeitar as leis e as instituições do país, mesmo em situações de crise (37\% mais), são fatores favoráveis à capacidade de responder a pergunta. Um aspecto importante tem de ser destacado aqui: as razões de chance da variável relativa ao papel da mídia (e, portanto, da difusão internacional da democracia) não apresenta nenhum resultado espetacular, indicando que embora ela conte quando considerada em conjunto com os outros fatores incluídos no modelo, a sua capacidade de explicação não tem a força suposta por parte da literatura discutida antes. Saber o que é democracia está ligado também a outros fatores como indicado a seguir. Entre as variáveis de avaliação do funcionamento das instituições, a crença de que os partidos representam a população e os eleitores (em contraposição à noção de que eles representam basicamente os próprios políticos) e de que as eleições no país não estão sujeitas a fraudes são fatores determinantes das respostas sobre a democracia (nos dois casos, essa percepção aumenta em mais de $30 \%$ a chance das pessoas saberem o que é a democracia). Mas a percepção de que os políticos brasileiros usam o caixa dois (66\% mais de chance) e de que superfaturariam as obras públicas, como a maioria acredita que fazem os políticos (44\% a mais), são fatores determinantes da capacidade de responder o que é democracia, embora não a crença de que os brasileiros, no lugar dos políticos, usariam o caixa dois. Há nisto uma clara conexão entre a democracia vista como um ideal e as funções normativas atribuídas às instituições. No que se refere à avaliação dos serviços públicos, são os que avaliam negativamente a habitação e a previdência social os que têm mais chance de saber o que é a democracia, enquanto no caso dos transportes são os que têm uma avaliação positiva dos serviços. Aparentemente, os resultados são contraditórios, 
mas não é impossível que os mais críticos em relação a áreas de atendimento consideradas mais deficitárias - habitação e previdência social - são os que esperam mais do regime democrático, enquanto os que estão satisfeitos com os serviços de transportes públicos - de mais fácil acesso, em que pesem déficits existentes - podem manifestar-se assim porque acreditam que a situação relativamente positiva do setor deriva do funcionamento da democracia.

Em conjunto, os fatores listados dizem respeito tanto à tradição das teorias de cultura política, como às que enfatizam o desenho e o desempenho das instituições democráticas. O modelo adotado neste artigo mostra, ainda, que os preditores dos significados escolhidos pelos entrevistados para definir a democracia supõem o envolvimento das pessoas comuns com o mundo da política e com os mecanismos de escolha de governos: os que conversam sobre política com os outros (70\% mais chance) os que assinariam abaixo-assinados de petições ou de protestos ( $43 \%$ mais de chance), os que participariam de boicotes se necessário (35\% mais de chance) e os que votariam mesmo se o voto não fosse obrigatório (aproximadamente metade da amostra, com $30 \%$ a mais de chance) têm mais chance de saber o que é democracia. Os resultados sugerem que a memória do regime militar e a velha tradição brasileira de pouca participação na vida pública podem estar perdendo força na atualidade. Ao mesmo tempo, confirmando algumas hipóteses de Putnam (1998), a confiança interpessoal tem importância para os resultados relatados. Nos termos das análises de Linz e Stepan (1996), esses resultados sugerem que a adesão à democracia no Brasil - além da transformação das próprias instituições políticas -, está baseada em atitudes favoráveis ao regime, expressas na rejeição de alternativas que poderiam colocá-lo em risco, mas também em uma visão que reflete uma demanda quanto à qualidade da democracia: a preocupação com a situação da corrupção sugere ainda que existe na sociedade brasileira uma demanda por maior eficiência dos mecanismos de accountability.

\section{Breves conclusões}

O estudo sugere algumas conclusões. Em primeiro lugar, os dados mostram que, diferente do que pensam os céticos, a maior parte dos brasileiros é capaz de definir a democracia em termos que envolvem duas das mais importantes dimensões do conceito, isto é, por um lado, o princípio de liberdade e, por outro, os procedimentos e estruturas institucionais. Essas definições da democracia distinguem, claramente, este regime de suas alternativas concorrentes, ou seja, não são ideias vagas e imprecisas que, sob influência da difusão internacional, apenas reproduzem a imagem positiva adquirida pela democracia. Os testes mostram que as respostas majoritárias sobre a democracia, envolvendo as liberdades e os procedimentos do regime, são influenciadas pela atenção dos entrevistados às 
notícias políticas na TV, mas ao mesmo tempo, por valores políticos como a rejeição de alternativas autoritárias, o reconhecimento do papel das instituições de representação, o interesse pela vida pública e a participação política. Neste sentido, os dados confirmam os achados de Dalton, Shin e Jou (2007) sobre os entrevistados do Leste Europeu, da Ásia, da África e de outros países da América Latina: pessoas comuns, mesmo em ambientes não inteiramente favoráveis, sabem definir a democracia e essa definição está associada, por uma parte, com o seu apoio normativo ao regime, isto é, aos ideais que ele envolve e, por outra, com as expectativas que ele suscita a respeito do desempenho prático de suas instituições como meio de realizar aqueles ideais.

As definições de democracia dos brasileiros são influenciadas por alguns valores da cultura política e por sua percepção a respeito do desempenho das instituições, mas chama a atenção que, incluídas nos modelos de análise, as variáveis de avaliação do desempenho da economia e do governo do dia não se mostrem importantes para explicar as respostas dos entrevistados. As definições envolvendo as duas dimensões mais importantes do conceito de democracia . liberdades e procedimentos - são determinadas basicamente por valores e outros fatores políticos, como a avaliação da situação da corrupção e das instituições em geral, a escolaridade e a influência das informações transmitidas pela mídia. Da perspectiva da abordagem da qualidade da democracia isso significa que, no Brasil, a democracia é vista sim como expressão de procedimentos institucionais - a exemplo da participação em eleições, mas ao mesmo tempo como uma construção referida também a princípios e valores do regime, como as liberdades, que distinguem claramente o processo democrático das alternativas autoritárias. Como chamaram a atenção Inglehart e Welzel (2005), essas dimensões são fundamentais para a percepção do regime como causa e efeito do desenvolvimento humano, ou seja, como uma perspectiva que concebe os indivíduos como capazes de definirem os rumos e o sentido de suas vidas, o que implica que se reconheçam como livres e iguais para fazê-lo.

Uma nota final de cautela, no entanto, é necessária. Como observaram Dalton, Shin e Jou (2007), saber definir o que é a democracia é muito importante, mas é insuficiente per se para consolidar o regime porque o processo democrático exige mais do que a sua simples definição. O funcionamento do sistema democrático, assim como a sua qualidade, exige o envolvimento público com as instituições e o acompanhamento dos cidadãos - através da mídia, de partidos e de associações da sociedade civil - do desempenho de governos e do poder público. No caso brasileiro, o paradoxo representado por níveis elevados de contínua desconfiança dos cidadãos das instituições políticas poderia se constituir em um fator desfavorável para isso, uma vez que a desconfiança está associada com os déficits de funcionamento das instituições democráticas (MOISÉS, 1995; 2008b). 
Neste sentido, o fato de as definições comuns de democracia envolverem, no período de quase 20 anos de pesquisas, significados que se referem a valores humanos fundamentais como as liberdades políticas e individuais, e os meios que permitem torná-los efetivos, como os procedimentos assegurados pelo funcionamento das instituições democráticas, sugere uma possibilidade de saída do paradoxo. Os resultados sugerem que pode estar emergindo um novo padrão da cultura política dos brasileiros: diferente dos sinais apontados por estudos sobre países de tradição democrática frágil (ALMOND e VERBA, 1965), as visões da democracia das pessoas comuns no Brasil mostram-se mais complexas do que no passado e envolvem, ao mesmo tempo, valores humanos e os meios de sua realização, oferecendo uma base potencial de apoio político para a superação das atuais distorções e déficits institucionais. A percepção sobre a corrupção, por um lado, e sobre o papel dos partidos e instituições de representação, de outro, são exemplares nesse sentido. Nos significados atribuídos à democracia pelos brasileiros, pode estar contida a base do que Pippa Norris (1999), analisando casos de democracias consolidadas, chamou de cidadãos críticos. Com efeito, ao mesmo tempo em que os partidos são reconhecidos como indispensáveis à democracia, o seu desempenho concreto é severamente avaliado, como exemplifica a atitude de desconfiança dos cidadãos dos mesmos; mas mais do que querer eliminá-los, a maioria dos cidadãos parece estar dizendo que deseja que eles funcionem efetivamente como mecanismos de representação. A percepção razoavelmente sofisticada dos cidadãos brasileiros sobre a democracia pode servir de base para iniciativas de pressão sobre o sistema político no sentido da reforma das instituições de representação. Por último, a preocupação com a corrupção também mostra que existe uma demanda sobre o desempenho das instituições encarregadas da responsabilização de políticos e governos. Para um país cuja experiência democrática é relativamente recente, esses sinais não são de pouca importância.

\section{Referências Bibliográficas}

ALMOND, G. e VERBA, S. The Civic Culture: Political Attitudes and Democracy in Five Nations. Boston: Little Brown, 1965.

BAVISKAR, S. e MALONE, M. F. T. "What democracy means to citizens - and why it matters". Revista Europea de Estúdios Latinoamericanos y del Caribe, vol. 76, p.3.23, 2004. 
BRATTON, M; MATTES, R. e GYIMAH-BOADI, E. Public Opinion, Democracy and Market Reform in Africa. Cambridge: Cambridge University Press, 2004.

CAMP, R. Citizens Views of Democracy in Latin America. Pittsburgh: University of Pittsburgh Press, 2001.

DAHL, R. Political Oppositions in Western Democracies. New Haven: Yale University Press, 1971.

DALTON, R. J; SHIN, D. C. and JOU, W. "The meaning of democracy: democratic understanding in unlikely places". Paper to the Annual Meetings of the Midwest Political Science Association, Chicago, IL, 2007.

DIAMOND, L. \& MORLINO, L. Assessing the quality of democracy. Baltimore: The Johns Hopkins University Press, 2005.

2004

"The Quality of Democracy". Journal of Democracy, vol.15, n4, p.20-31,

DURAND PONTE, V. M. Ciudadanía y Cultura Política: México 1993-2001. México D.

F.: Ed. Siglo Veintiuno, 2004.

GAY, P. A Cultura de Weimar. Rio de Janeiro: Ed. Paz e Terra, 1978.

GUNTHER, R. and MONTERO, J. R. "Legitimacy, Satisfaction and Disaffection in New Democracies". Paper presented to the conference Political Disaffection in the European Democracies, Santiago de Compostela, 2000.

HUBER, E; RUESCHEMEYER, D. and STEPHENS, J. D. "The paradoxes of Contemporary Democracy: Formal, Participatory and Social Democracy". Comparative Politics, vol. 29 n³, p.323-42, 1997.

HUNEEUS, C. Chile, un país dividido. Santiago: Catalonia, 2003.

HUNTINGTON, S. P. The third wave: democratization in the Late Twentieth Century. Norman: University of Oklahoma Press, 1991.

INGLEHART, R. "How Solid is Mass support for Democracy - and how can we measure it". Political Science and Politics, vol. 36, n01, 2003.

INGLEHART, R. and WELZEL, C. Modernization, Cultural Change and Democracy. New York: Cambridge University Press, 2005.

KARL, T. L. Electoralism, In: ROSE, R. et al. The international encyclopedia of elections. Washington DC: Congressional Quarterly Press, 2000. 
KLINGEMANN, H-D. Mapping Political Support in the 1990s: A Global Analysis. In: NORRIS, P. (ed.). Criticial Citizens: Global Support for Democratic Governance, Oxford: Oxford University Press, 1999.

KLINGEMANN, H.D. and FUCHS, D. (orgs.). Citizens and the State. Oxford: Oxford University Press, 1998.

LINZ, J. J. and STEPAN, A. Problems of Democratic Transition and Consolidation. Baltimore: The Johns Hopkins University Press, 1996.

MENEGUELLO, R. "Trust in government and democratic adherence in Brazil: 2002. 2006", paper to the Seminar 'Democracy and Distrust of Public Institutions in Brazil in comparative perspective'. Center for Brazilian Studies, University of Oxford, 2007.

. Tendencias Electorales tras 12 años de democracia. In: SÁEZ, A. M. y MELO, C. R. (eds). La Democracia Brasileña. Balance y Perspectivas para el Siglo XXI. Salamanca: Ediciones Universidad Salamanca, 2008.

MILLER, A. H. and LISTHAUNG, O. "Conceptions of Democracy Across Mass and Elite in Post-Soviet Societies". British Journal of Political Science, vol. 29, p.553-581, 1999.

MOISÉS, J. A. Os Brasileiros e a Democracia: bases sócio-políticas da legitimidade democrática. São Paulo: Ática, 1995.

p.33.63, 2005.

"A desconfiança das instituições democráticas". Opinião Pública, vol. XI, n¹,

"Democracy, Trust and Democratic Institutions in Brazil". Revised version of a paper presented to the 20 th IPSA World Congress, Fukuoka, July, 8-13, 2007.

"Democracia, desconfiança política e insatisfação com o regime - o caso do Brasil". Opinião Pública, Campinas, vol. 14, n 1, p.1-42, jun. 2008.

"Cultura Política, Instituições e Democracia - lições da experiência brasileira". Revista Brasileira de Ciências Sociais, Vol. 23, n 66, p.11.44, fev. 2008.

NEUMAN, W. R. The Paradox of Mass Politics. Cambridge: Harvard University Press, 1986.

NORRIS, P. Critical Citizens: Global Support for Democratic Government. Oxford:

Oxford Univ. Press, 1999.

NYE, J. S., ZELIKOW, P. D, e KING, D. C. Why People Don't Trust Government. Cambridge, Mass.: Harvard University Press, 1997. 
PORTO, M. "La Crisis de Confianza en la Politica y sus Instituciones: Los Medios Y la Legitimidad de la Democracia en Brasil". America Latina hoy, n² 25, p.23-33, 2000.

PUTNAM, R. Making Democracy Work. Princeton: Priceton University Press, 1993.

RUSTOW, D. "Transitions to Democracy". Comparative Politics, vol.2, n² 2, p.337-63, 1970.

SCHAFFER, F. G. Democracy in Translation: Understanding Politics in an Unfamiliar Culture. Ithaca, NY: Cornell University Press, 1998.

SCHELER, A. and SARSFIELD, R. "Democratas with adjectives: Linking direct and indirect measures of democratic support". Afrobarometer Working-paper, n 45, 2004.

SCHUMPETER, J. A. Capitalism, Socialism and Democracy. New York: Harper Torchbooks, 1950.

SHIN, D. C. "Popular Support for Democracy and Institutional Trust in Korea", original não publicado, 2005.

TOCQUEVILLE, A. A Democracia na América. São Paulo: Edusp, 1969.

WEBER, M. Ensaios de Sociologia e Outros Escritos. São Paulo: Abril Cultural, 1974. 


\section{ANEXO 1 \\ Recodificação das respostas à pergunta 'o que é democracia' - 1989 a 2006}

\begin{tabular}{|c|c|}
\hline Liberdades - menções a: & Direitos e deveres legislados e aplicados \\
\hline Liberdade de criticar o governo & Punir Políticos que roubam o povo \\
\hline Direito de ir e vir & Fins Sociais - Menção a: \\
\hline Liberdade de expressar-se & $\begin{array}{l}\text { Direito à saúde pública independente de raça, sexo, } \\
\text { cor }\end{array}$ \\
\hline Poder lutar por melhores salários & Direito a um transporte digno \\
\hline $\begin{array}{l}\text { Todos podem exercer seus direitos } \\
\text { Liberdade para organizar-se }\end{array}$ & Direito a trabalho \\
\hline Liberdade sem repressão & $\begin{array}{l}\text { Governo dar melhores condições de vida para as } \\
\text { pessoas de baixa renda }\end{array}$ \\
\hline Liberdade de informação & País com muito trabalho, onde não falte emprego \\
\hline Governo garantir a segurança do povo & Direitos iguais entre os povos \\
\hline Direito de opinar & Igualdade entre os cidadãos \\
\hline Consciência de direitos e deveres & Igualdade entre homens e mulheres/direitos iguais \\
\hline País livre onde não se vive como escravos & Não ter discriminação de cor/raça \\
\hline Procedimentos/Instituições - menções a: & Inconsistentes/NS/NR \\
\hline Cidadão exercer seus direitos e deveres & É violência \\
\hline Obrigação de votar & Falta de respeito ao cidadão \\
\hline Necessidade de leis severas & É bom \\
\hline Governo não ser corrupto & Brigas entre políticos / Brigas na política \\
\hline $\begin{array}{l}\text { Partidos políticos c/ igual espaço nos meios } \\
\text { de comunicação }\end{array}$ & País com política honesta \\
\hline Governo com leis através de um parlamento & Não cumprimento das leis \\
\hline País governado pelo Congresso & Presidente corrupto no governo / políticos \\
\hline Cumprimento da Constituição & Diferença entre ricos e pobres / desigualdade social \\
\hline Povo poder fiscalizar o governo & Discriminação entre raças \\
\hline Organização do povo respeitando as leis & Falta de honestidade \\
\hline Governo cumprir com suas obrigações & $\begin{array}{l}\text { Governantes impor leis não compatíveis com as } \\
\text { necessidades do povo }\end{array}$ \\
\hline Forma de governo & Regime dominado por políticos da elite \\
\hline $\begin{array}{l}\text { Governo com participação de todas as classes } \\
\text { sociais }\end{array}$ & Sistema onde todo mundo manda \\
\hline Governo onde vence a maioria & Não sabe/ Não repondeu \\
\hline É saber exigir seus direitos, cobrar seus direitos & Regime dominado por políticos da elite \\
\hline País onde leis para ricos e pobres são as mesmas & Sistema onde todo mundo manda \\
\hline Direito dos cidadãos serem reconhecidos por lei & \\
\hline Mesma lei para ricos e pobres & \\
\hline $\begin{array}{l}\text { Equilíbrio entre três poderes: judiciário, legislativo } \\
\text { e executivo }\end{array}$ & \\
\hline Respeito ao cidadão & \\
\hline
\end{tabular}




\section{ANEXO 2}

Variáveis binárias utilizadas na análise bivariada, mas na Tabela 4 foram incluídas apenas as variáveis que significantes. Atributo $=1$; outros $=0$.

\begin{tabular}{|c|c|}
\hline Renda mensal familiar (baixa - até $\mathrm{R} \$ 780,00$ ) & $\begin{array}{l}\text { O Brasil seria melhor se existisse apenas um } \\
\text { partido político }\end{array}$ \\
\hline Idade (acima de 39 anos) & Só uma ditadura daria jeito no Brasil \\
\hline Regiões (Sul e Sudeste) & Votaria mesmo que o voto não fosse obrigatório \\
\hline Sexo masculino & Existe igualdade perante a lei \\
\hline Cidades com mais de 500 mil habitantes & Os brasileiros são cumpridores das leis \\
\hline $\begin{array}{l}\text { Escolaridade (baixa: analfabetos e até colegial } \\
\text { incompleto) }\end{array}$ & A lei deve ser obedecida sempre \\
\hline $\begin{array}{l}\text { Preferência por regime: democracia } \\
\text { Democracia está associada com: }\end{array}$ & Os brasileiros fazem valer os seus direitos \\
\hline Direito de escolher governo & Os brasileiros são conscientes de suas obrigações \\
\hline Liberdades políticas & Os brasileiros são conscientes de seus direitos \\
\hline Igualdade social & Sente-se próximo de partidos políticos brasileiros \\
\hline Igualdade perante a lei & Votou nas últimas eleições presidenciais (2002) \\
\hline Fiscalização dos atos do governo pelo Congresso & Confiança interpessoal \\
\hline $\begin{array}{l}\text { Menos corrupção e controle do tráfico de } \\
\text { influência }\end{array}$ & Confiança no Poder Judiciário \\
\hline Educação, saúde e emprego & Confiança no Congresso Nacional \\
\hline $\begin{array}{l}\text { Fiscalização do governo pelo Ministério Público e } \\
\text { Tribunais de Justiça }\end{array}$ & Confiança nos Partidos Políticos \\
\hline Igualdade de direitos para as mulheres & Confiança no Governo \\
\hline Liberdades em questões morais & As eleições no Brasil são limpas e honestas \\
\hline Multipartidarismo & Nos últimos 5 anos a corrupção não aumentou \\
\hline A democracia não pode funcionar sem partidos & No último ano a corrupção não aumentou \\
\hline $\begin{array}{l}\text { A democracia não pode funcionar sem Congresso } \\
\text { Nacional }\end{array}$ & Está satisfeito com a democracia \\
\hline Os partidos são indispensáveis à democracia & Avaliação positiva da situação política do país \\
\hline $\begin{array}{l}\text { O Presidente da República deve ser identificado } \\
\text { com um partido político }\end{array}$ & $\begin{array}{l}\text { Apesar de problemas, democracia é melhor forma } \\
\text { de governo }\end{array}$ \\
\hline $\begin{array}{l}\text { Partidos políticos são necessários para o } \\
\text { progresso do país }\end{array}$ & $\begin{array}{l}\text { O governo pode passar por cima das leis e das } \\
\text { instituições do país para resolver uma situação } \\
\text { difícil }\end{array}$ \\
\hline $\begin{array}{l}\text { Deputados e Senadores são necessários para o } \\
\text { progresso do país }\end{array}$ & $\begin{array}{l}\text { A situação econômica melhorou durante o } \\
\text { governo Lula }\end{array}$ \\
\hline $\begin{array}{l}\text { Tribunais de Justiça são necessários para o } \\
\text { progresso do país }\end{array}$ & $\begin{array}{l}\text { A situação econômica melhorou durante o } \\
\text { governo } \mathrm{FHC}\end{array}$ \\
\hline $\begin{array}{l}\text { Prefere a democracia a um líder salvador não } \\
\text { controlado por leis }\end{array}$ & $\begin{array}{l}\text { A situação econômica melhorou durante a } \\
\text { Ditadura Militar }\end{array}$ \\
\hline $\begin{array}{l}\text { Se o país enfrenta dificuldades, o presidente pode } \\
\text { tomar as decisões sozinho independentemente do } \\
\text { Congresso e das leis }\end{array}$ & $\begin{array}{l}\text { Os Direitos Humanos melhoraram durante o } \\
\text { governo FHC }\end{array}$ \\
\hline $\begin{array}{l}\text { O país funcionaria melhor se os militares } \\
\text { voltassem ao poder }\end{array}$ & $\begin{array}{l}\text { Os Direitos Humanos melhoraram durante o } \\
\text { governo Lula }\end{array}$ \\
\hline $\begin{array}{l}\text { Daria um cheque em branco a um líder salvador } \\
\text { que resolvesse os problemas do país }\end{array}$ & $\begin{array}{l}\text { Os Direitos Humanos melhoraram durante a } \\
\text { Ditadura Militar }\end{array}$ \\
\hline
\end{tabular}




\section{ANEXO 3}

\section{Variáveis utilizadas na análise fatorial (Tabela 5)}

Interesse por política; Até 2 horas de TV por dia; Atenção em notícias políticas na TV; Baixa escolaridade; Cidades + 500 mil habitantes; Democracia é melhor forma de governo; Preferência por regime democrático; Democracia=direito de escolher governo; Democracia=liberdades políticas; Democracia=igualdade social; Democracia=igualdade perante a lei; Democracia=fiscalização do governo pelo Congresso; Democracia=controle da corrupção e tráfico de influência; Democracia=atendimento necessidades saúde, emprego e educação; Democracia=fiscalização do governo p/ tribunais de justiça e Ministério Público; Democracia=direitos das mulheres; Democracia=liberdades morais e sexuais; Partidos são necessários p/ democracia; Congresso é necessário $\mathrm{p} /$ democracia; Proximidade de partidos; Partidos indispensáveis p/ democracia; Presidente deve ser identificado com partido; Partidos são necessários ao país; Deputados e Senadores são necessários ao país; Tribunais são necessários ao país; Votou nas últimas eleições; Votaria se o voto não fosse obrigatório; Sabe o que é democracia.

\section{ANEXO 4}

\section{Variáveis utilizadas na regressão logística (Tabela 6)}

Sexo (homens), Escolaridade (média ou mais), Renda (+ de R\$1.300), PEA (integra), Cidades (+ 500 mil habitantes), Região (sul e sudeste), Confia na maioria das pessoas, Religião (católicos), Cor (brancos), Presta atenção às notícias políticas na TV, Tem interesse por política, Acha q. Governo deve respeitar leis e instituições em crises, Rejeita o retorno dos militares, Rejeita sistema de partido único, Votaria se voto não fosse obrigatório, Conversa sobre política, Assinaria abaixo-assinados, Participaria de boicotes, Participa de comunidades religiosas, Existe igualdade perante a lei, Partidos representam a população e os eleitores, Eleições são limpas, Acha q. governo deve intervir + na economia, Funcionários não levam em conta a opinião dos cidadãos, Órgãos públicos não prestam informações aos cidadãos, Confia na policia, Confia no Congresso Nacional, Prefeituras são necessárias ao país, Avalia bem habitação, Avalia bem previdência social, Avalia bem transportes, A maioria dos políticos usam caixa 2 em campanhas eleitorais, Brasileiros, no lugar dos políticos, usariam caixa dois, Brasileiros, no lugar dos políticos, superfaturariam obras públicas, Situação econômica familiar é boa, Votou em Lula, Situação econômica do país melhorou com o governo Lula.

José Álvaro Moisés - jamoises@gmail.com

Recebido para publicação em fevereiro de 2010. Aprovada para publicação em maio de 2010. 